\title{
O JUDICIÁRIO COMO IMPULSIONADOR DOS DIREITOS FUNDAMENTAIS: ENTRE FRAQUEZAS E POSSIBILIDADES
}

\author{
JUDICIARY AS BOOSTER OF FUNDAMENTAL RIGHTS: BETWEEN WEAKNESSES \\ AND POSSIBILITIES
}

Jane Reis Gonçalves Pereira ${ }^{1-2}$

RESUMO: O presente artigo avalia as deficiências e as possibilidades de fortalecimento da jurisdição dos direitos fundamentais no Brasil. Primeiro, explora-se de que forma a tutela dos direitos fundamentais desenvolveu-se no Poder Judiciário após 1988. Em seguida, discute-se de que maneira a progressiva concentração de poder no STF contribui para a proteção dos direitos humanos, bem como de que maneira ela debilita essa proteção. Ao fim, são apresentadas propostas para tornar os direitos fundamentais uma pauta prioritária e relevante - no Supremo e no Poder Judiciário como um todo, ampliando os canais de acesso e aproximando a lógica do processo judicial dos instrumentos de exercício da cidadania.

PALAVRAS-CHAVE: Direitos Fundamentais; Acesso à justiça; Ativismo judicial.

ABSTRACT: The present article analyzes the deficiencies and the alternatives to strengthen the protection of fundamental rights by the brazilian judicial review system. Firstly, it summarizes the development of the judicial protection of human rights in the last decades. Afterwards, the study discusses how the concentration of power in the Brazilian Supreme Court (promoted by constitutional amendments and legal reforms) facilitates the protection of fundamental rights, and how it makes the system more difficult to access by marginalized groups. At last, it addresses some proposals to make the safeguard of fundamental rights a priority task in courts, widening the access channels and making procedural rules more friendly to citizens.

KEY WORDS: Fundamental rights; Access to justice; Judicial activism.

\footnotetext{
${ }^{1}$ Doutora em Direito Público pela UERJ. Mestre em Direito Constitucional e Teoria do Estado pela PUC-Rio. Professora Adjunta de Direito Constitucional da UERJ. Juíza Federal. Email: janergp@ gmail.com

${ }^{2}$ Agradeço imensamente a ajuda inestimável prestada por Renan Medeiros na pesquisa e edição deste artigo.
} 


\section{INTRODUÇÃO: O JUDICIÁRIO ENTRE IMPULSÃO E ENFRAQUECIMENTO DOS MOVIMENTOS EMANCIPATÓRIOS}

De que forma o Judiciário pode impulsionar e sedimentar a revolução dos direitos fundamentais iniciada com a Constituição de 1988? De um lado, os atores jurídicos nutrem a esperança de que as frágeis armas do Direito - textos normativos, argumentos jurídicos, persuasão - possam ser utilizadas como ferramentas de emancipação e de transformação social. Espera-se que essas armas sejam eficientes contra a opressão e o obscurantismo, e que possam ser invocadas e corrigir rumos nos cenários em que as engrenagens da democracia falham ${ }^{3}$.

De outro lado, é justa a apreensão de que a ribalta do Direito ilumine excessivamente o papel dos juízes, que os torne protagonistas aristocráticos da democracia, enfraquecendo os movimentos sociais, desencorajando a participação política e removendo a centralidade das instâncias tradicionais de representação popular ${ }^{4}$. Esse é o grande dilema com o qual a dogmática dos direitos fundamentais precisa conviver. $\mathrm{O}$ discurso jurídico se apoia na premissa de que o Judiciário é apto a retificar as falhas da democracia, mas é sistematicamente assombrado pelo receio persistente de que a ampliação do poder dos juízes promova um efeito de abrandamento das lutas sociais e fragilização da democracia (MAUS, 2000).

A celebrada gramática dos direitos fundamentais corresponde à linguagem particular empregada para a proteção estatal de grupos marginalizados, envolvendo um projeto de emancipação e inclusão a partir de certos direitos morais que o sistema jurídico converteu em direitos legais, tais como dignidade humana, igualdade, liberdade de expressão e privacidade ${ }^{5}$. É certo, porém, que esse mesmo sistema que busca incluir e libertar encerra uma faceta opressiva, pois impõe que grupos heterogêneos adaptem suas fórmulas de pensamento e de linguagem àquela que rege o aparato estatal, adaptando-se a uma lógica que é própria do poder e das relações verticais de autoridade. Ao mesmo tempo, atores sociais podem ser reduzidos, nesse processo, à figura ancestral do sujeito de direito, que se limita a exigir o cumprimento de uma decisão emanada do Estado, em oposição ao cidadão que opera para

\footnotetext{
${ }^{3}$ No Brasil, Barroso (2015) é expoente de uma leitura otimista em relação ao papel do judiciário.

${ }^{4}$ É vasta a bibliografia crítica ao protagonismo do Judiciário. Sobre o tema, v. Pereira (2014).

${ }^{5} \mathrm{O}$ conceito de direitos morais é explorado por Santiago Nino. Sobre o tema, v. Pereira (2002).
} 
construir essas decisões. Outra crítica à proteção judicial dos direitos consiste no fato de que, muitas vezes, os titulares dos direitos não se engajam diretamente nas demandas jurídicas, que operariam, segundo essa leitura, de cima para baixo, pois que não raro aqueles que têm seus direitos violados não têm vozes ativas nos debates legais, os quais são protagonizados por advogados e agentes estatais que se encarregam de traduzir as demandas para a linguagem jurídica. Os direitos humanos judicializados, segundo essa leitura crítica, encerram o risco de restarem subservientes à configuração legalista e estatista que o processo impõe. Essas objeções, eventualmente colocadas quanto aos órgãos de proteção de direitos humanos (PERUGINI, 2015; ANDERSON, 2011, p. 361), podem ser parcialmente aplicáveis ao modelo de tutela dos direitos que a Constituição de 1988 consagrou. A questão que se coloca é: existe um trade-off entre judicialização e amadurecimento das lutas sociais? O modelo de proteção dos direitos via Judiciário contribui para o enfraquecimento da cidadania?

Essa questão tem como anteparo teórico a tensão ancestral entre direitos e democracia. Há três linhas de pensamento predominantes quando se trata de opinar sobre as vantagens de deslocar os conflitos envolvendo direitos para o poder judicial. Há quem visualize as cortes como protagonistas naturais nessas questões, porquanto dispõem de características que as colocam numa posição privilegiada para solucionar embates jurídicos com substrato moral. Essa ideia está presente, por exemplo, no pensamento de Ronald Dworkin, para quem o controle de constitucionalidade provê um "fórum de políticas (forum of politics) no qual os cidadãos podem participar argumentativamente, se quiserem, e, portanto, de uma forma mais diretamente conectada às suas vidas morais do que votar quase sempre é" (DWORKIN, 1987, p. 29). Fazendo uma análise de cunho institucional, Christopher Eisgruber (2001) também retrata de forma favorável e idealizada o papel das cortes como instância de proteção dos direitos, destacando que os juízes desfrutam de uma posição institucional singular e privilegiada, que lhes assegura a possibilidade de atuar como autoridades desinteressadas ${ }^{6}$. Outras leituras, em sentido antagônico, são severamente críticas à atuação dos juízes no equacionamento das grandes controvérsias sobre direitos e liberdades. O eixo central dessas doutrinas é a rejeição ao viés elitista do modelo de constitucionalismo que atribui aos juízes o poder de dar a última palavra em controvérsias agudas. Em geral, os críticos ao protagonismo das cortes vislumbram na jurisdição constitucional um inexpugnável caráter antidemocrático.

\footnotetext{
${ }^{6}$ Não cabe aqui inventariar todas as teses relacionadas ao papel e à legitimidade dos juízes. Um bom panorama pode ser encontrado em Zurn (2014).
} 
Revista da Faculdade de Direito-RFD-UERJ - Rio de Janeiro, n. 29, jun. 2016

São exemplares dessa postura o grupo de autores que integra o movimento teórico heterogêneo que tem sido chamado de constitucionalismo popular ${ }^{7}$. Essa linha é composta por autores como Larry Kramer (2001) e Mark Tushnet (1999), os quais, descritiva e prescritivamente, sustentam que o Judiciário não precisa nem deve ocupar uma posição central na construção de direitos, razão por que o poder de dar a palavra final sobre questões constitucionais deve ser retirado dos tribunais e devolvido ao povo. Também na vertente crítica ao poder judicial, merece registro a célebre formulação de Jeremy Waldron (2006), para quem as decisões produzidas pelo Legislativo devem ter preferência sobre aquelas produzidas pelos juízes, pois aquele, mesmo quando produz deliberações ruins e erradas, dispõem da vantagem institucional de promover a autodeterminação do povo. São também interessantes, na linha crítica ao poder conferido aos juízes, as objeções feitas por Ingeborg Maus (2000) à centralidade que a sociedade alemã conferiu à Corte Constitucional. A autora destaca que a elevação do Judiciário à condição de guardião da moral pública resulta no enfraquecimento da democracia, pois que submete os cidadãos à uma tutela de tipo patriarcal, que reduz sua autonomia ${ }^{8-9}$.

Uma proposta bem elaborada no sentido de conciliar judicialização e autodeterminação popular é o modelo de constitucionalismo democrático proposto por Robert Post e Reva Siegel. Segundo esses autores, muitas decisões dadas pelo direito constitucional constituem respostas à mobilização popular. Esse fenômeno não equivale a negar a distinção entre direito e política, mas reconhecer que a tensão entre estado de direito e autogoverno é negociada e desejável. Dessa forma, certo grau de conflito e discordância é uma consequência natural de reivindicar direitos pela via judicial, de modo que a interpretação constitucional pelas cortes pode funcionar como um incentivo à participação política e ao engajamento do povo (POST; SIEGEL, 2007). Nessa ordem de argumentos, as decisões judiciais estão incrustadas no sistema constitucional e as reações que provocam podem promover um intercâmbio entre intérpretes oficiais e cidadãos. As pressões e críticas ao Judiciário, ao contrário de debilitar os fundamentos da atuação judicial, servem para legitimar o controle de

\footnotetext{
${ }^{7}$ Sobre a dificuldade de definir e agrupar as doutrinas do constitucionalismo popular veja-se Gomes (2014, p. 30).

8 “Quando a Justiça ascende ela própria à condição de mais alta instância moral da sociedade, passa a escapar de qualquer mecanismo de controle social”' (MAUS, 2000, p. 187).

${ }^{9}$ No plano das análises descritivas também não há consenso quanto aos efeitos da judicialização nas conquistas sociais. Há estudos que apontam uma correlação entre vontade do povo e ação transformadora das cortes (FRIEDMAN, 2009; LAIN, 2012; DAHL, 1957), enquanto outros desacreditam que o Judiciário possa efetivamente operar mudanças sociais (ROSENBERG, 1991).
} 
constitucionalidade como uma das ferramentas da intrincada teia democrática. Essa leitura é particularmente adequada ao modelo brasileiro, no qual os acentuados defeitos e inconsistências da representação motivados pela desigualdade estrutural tornam particularmente necessária a tutela legal de direitos, bem como parece clara a necessidade de o Judiciário democratizar-se e tornar-se mais poroso às demandas sociais e mais acessível pelos grupos vulneráveis. É essa ideia que o presente artigo pretende explorar.

Fixadas essas premissas teóricas, passarei a avaliar as possibilidades de fortalecimento da jurisdição dos direitos fundamentais, sem perder de vista os riscos que o incremento da judicialização encerra. Os argumentos aqui expostos estão estruturados em três blocos. No primeiro, explorarei, em linhas mais largas, de que forma a tutela dos direitos fundamentais se desenvolveu no Poder Judiciário após 1988. Em seguida, buscarei discutir um ponto que tem sido deixado em segundo plano: de que maneira a progressiva concentração de poder no STF, ou seja, a intensa verticalização da jurisdição constitucional, contribui para a proteção dos direitos humanos, bem como de que maneira ela debilita essa proteção. Ao fim, apresento algumas ideias preliminares sobre formas de tornar os direitos fundamentais uma pauta prioritária e relevante - no Supremo e no Poder Judiciário como um todo, ampliando os canais de acesso e aproximando a lógica do processo judicial dos instrumentos de exercício da cidadania.

\section{A TUTELA DOS DIREITOS FUNDAMENTAIS APÓS 1988}

Qualquer um que acompanhe noticiário ou estude a aplicação jurídica dos direitos fundamentais, hoje, terá a percepção de que o Supremo Tribunal Federal é o principal protagonista na sua tutela ${ }^{10}$. Nos últimos anos, a ascensão institucional do Supremo desencadeou um aumento exponencial na produção acadêmica sobre o tribunal, que passou a ter grande visibilidade e a ser percebido como o principal agente de proteção dos direitos humanos ${ }^{11}$.

\footnotetext{
${ }^{10}$ Veja-se, a propósito, Pereira (2009).

${ }^{11}$ Nesse sentido, afirma Oscar Vilhena Vieira que na academia, "multiplica-se o número de trabalhos destinados a analisar os diversos aspectos da vida e da atuação do Supremo, seja nas faculdades de direito, seja nos programas de ciência política, sociologia, história, etc. O tema da interpretação constitucional que, no passado, ocupava um espaço residual na preocupação dos nossos constitucionalistas, passou a ser o principal foco de atenção de uma nova geração de juristas" (VIEIRA, 2008, p. 442). Além disso, "é difícil pensar um tema relevante da vida política contemporânea que não tenha reclamado ou venha a exigir a intervenção do Supremo
} 
Revista da Faculdade de Direito-RFD-UERJ - Rio de Janeiro, n. 29, jun. 2016

A criação TV Justiça ${ }^{12}$ e a ampla cobertura da mídia contribuíram fortemente para essa percepção de centralidade do Supremo como guardião das liberdades. Inequivocamente, houve avanços importantes e a democratização do acesso aos argumentos usados nos julgamentos sobre direitos fundamentais geraram muitos efeitos positivos. No entanto, é importante destacar que a maior preocupação dada pelo STF aos temas envolvendo direitos fundamentais é um fenômeno relativamente recente.

A jurisdição constitucional da década de 90 foi marcada pelo que se pode chamar de direito da burocracia. O STF, ao longo da década de 90, era um tribunal passivista, autocontido, deferente ao Executivo e que priorizava ações que envolviam questões patrimoniais (BARROSO, 2013a; CAMPOS, 2013), sobretudo aquelas que abrangiam o aparato burocrático do Estado. Os julgamentos mais importantes dessa década compreenderam questões relacionadas aos planos econômicos, aos direitos dos servidores públicos e ao direito tributário ${ }^{13}$. Os direitos fundamentais - sobretudo os direitos de caráter existencial - não estavam colocados como uma questão relevante ou prioritária para o Supremo.

Nesse sentido, um aspecto interessante relacionado ao comportamento e às prioridades do Tribunal é o fato de não ter tido sua composição renovada com o advento da Constituição

Tribunal Federal. (...) Em resumo, tudo no Brasil parece exigir uma 'última palavra' do Supremo Tribunal Federal." (Idem, 2008, p. 451).

${ }^{12}$ Felipe Fonte (2016) pontua que a evolução da tecnologia e o crescente número de pessoas com acesso a ela trouxe o tema do judiciário como o poder menos compreendido de volta ao debate, motivando o acesso a fóruns por meio da internet e do televisionamento. Neste cenário, o autor aponta como argumentos favoráveis ao televisionamento: a proteção das pessoas contra os riscos decorrentes da arbitrariedade judicial; a legitimidade para o exercício das funções estatais; a educação do público, já que todos poderiam aprender sobre a lei e o Direito; e os potenciais efeitos preventivos, pois ao ver a condenação de malfeitores a população se sentiria encorajada a cumprir a lei. Contrariamente, porém, aponta-se que há efeitos adversos desconhecidos sobre o comportamento humano decorrentes do televisionamento, já que as condições institucionais necessárias para uma decisão poderiam estar comprometidas, sobretudo em temas socialmente sensíveis; a justiça poderia ser transformada em entretenimento, com a perda de respeito da população; e a intimidade e a privacidade das partes envolvidas no processo televisionado poderia ser posta em risco.

Ainda sobre o televisionamento das Cortes, v. Stepniak (2008), Tuma (2001), Mcelroy (2012), Cohn e Dow (1998), Baum (2006) e Alexander (2003).

${ }^{13}$ A título de exemplo, v., respectivamente, decisões sobre correção monetária de FGTS decorrente dos planos econômicos Bresser, Verão e Collor I e II; sobre provimento derivado de servidores de cargos extintos em carreira distinta; sobre a extensão a servidores aposentados de vantagens concedidas a servidores ativos; e sobre a inadmissão da progressividade do IPTU: BRASIL. Supremo Tribunal Federal. Recurso Extraordinário $\mathrm{n}^{\circ}$ 226855, Tribunal Pleno, Rel. Min. Moreira Alves, julgado em 31 ago. 2000, publicação em 13 out. 2000; BRASIL. Supremo Tribunal Federal. Ação Direta de Inconstitucionalidade no 2335 MC, Tribunal Pleno, Rel. Min. Maurício Corrêa, julgado em 19 dez. 2000, publicação em 31 ago. 2001; BRASIL. Supremo Tribunal Federal. Recurso Extraordinário no 173682, Primeira Turma, Rel. Min. Sydney Sanches, julgado em 22 out. 1996, publicação em 19 dez. 1996; BRASIL. Supremo Tribunal Federal. Recurso Extraordinário $\mathrm{n}^{\circ}$ 153771, Tribunal Pleno, Rel. Min. Carlos Velloso, Rel. p/ acórdão Min. Moreira Alvez, julgado em 20 nov. 1996, publicação em 05 set. 1997. 
de 1988. Foram mantidos, na transição, os ministros nomeados pelo regime precedente. Por isso, não chega a ser surpreendente que, no começo da década de 90 as maiores conquistas em matéria de direitos tenham sido estabelecidas predominantemente pela via legislativa, e, também, por meio de decisões tomadas pela base do Judiciário, mais jovem e parcialmente renovada pelos concursos públicos. No plano Legislativo, foram marcantes a aprovação do Estatuto da Criança e do Adolescente (Lei nº 8.069/90), das Leis de Previdência e Assistência Social (Leis $\mathrm{n}^{\circ} 8.212 / 91, \mathrm{n}^{\circ} 8.213 / 91$ e $\mathrm{n}^{\circ}$ 8.742/93) e do Código de Defesa do Consumidor (Lei $\left.n^{\circ} 8.078 / 90\right)$. Na atuação da primeira instância, tiveram um papel importante as ações de fornecimento de medicamentos, especialmente fornecimento de medicamentos para a AIDS (MINISTÉRIO DA SAÚDE, 2005, p. 99 e ss.), as ações relacionadas aos expurgos inflacionários ${ }^{14}$, bem como o desbloqueio dos cruzados ${ }^{15}$. Nesse mesmo período, estabeleceuse uma jurisprudência protetiva do consumidor ${ }^{16}$ e dos segurados da previdência ${ }^{17}$. No âmbito do direito de família, a proteção das uniões estáveis, assegurada pela Constituição e naquele momento ainda não contemplada pelo Direito Civil foi inicialmente impulsionada pelo

${ }^{14}$ Como afirma Virgílio Afonso da Silva, "[d]esde o início, o Poder Judiciário foi o porto seguro onde os cidadãos puderam fazer valer seus direitos contra o confisco perpetrado pelo governo de então." (SILVA, V., 2012).

15 BRASIL. Supremo Tribunal Federal. Ação Direta de Inconstitucionalidade ${ }^{\circ}$ 534, Tribunal Pleno, Rel. Min. Celso de Mello, julgado em 26 ago. 1992, DJ 08 abr. 1994; BRASIL. Supremo Tribunal Federal. Recurso Extraordinário $\mathrm{n}^{\circ}$ 149587, Tribunal Pleno, Rel. Min. Moreira Alves, julgado em 26 ago. 1992, DJ 04 set. 1992 ; BRASIL. Tribunal Regional Federal da $1^{\text {a }}$ Região. Apelação Cível n ${ }^{\circ} 00248088519924010000,3^{\text {a }}$ Turma, Rel $^{\text {a }}$. Des $^{\text {a }}$ Sônia Diniz Viana, julgado em 02 out. 1998, DJ 18 dez. 1998; BRASIL. Tribunal Regional Federal da 5 Região, Remessa Ex Officio n ${ }^{\circ}$ 5746, $2^{\text {a }}$ Turma, Rel. Des. Nereu Santos, julgado em 31 mar. 1992, DJ 03 jul. 1992; BRASIL. Tribunal Regional Federal da $2^{\mathrm{a}}$ Região, Apelação Cível $\mathrm{n}^{\circ}$ 9202186804, $2^{\mathrm{a}}$ Turma, Rel. Des. Alberto Nogueira, julgado em 06 out. 1993; BRASIL. Tribunal Regional Federal da $2^{\text {a }}$ Região, Mandado de Segurança $\mathrm{n}^{\circ}$ 9202022658, $1^{\text {a }}$ Turma, Rel. Des. Frederico Gueiros, julgado em 10 jun. 1992; BRASIL. Tribunal

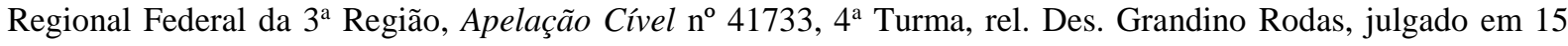
mai. 1991, DJU 05 ago. 1991.

${ }^{16}$ A jurisprudência relativa ao Direito do Consumidor passou a incorporar o dirigismo contratual e a intervir em contratos formados pela autonomia privada caracterizando, em alguns casos, cláusulas que violem direitos do consumidor como nulas de pleno direito. Neste sentido, v., a título de exemplo: BRASIL. Tribunal de Justiça do Rio de Janeiro. Apelação no 0003130-38.1996.8.19.0000, 2a Câmara Cível, Rel. Des. Sergio Cavalieri Filho, julgado em 17 abr. 1996; BRASIL. Tribunal de Justiça do Rio de Janeiro. Apelação $\mathrm{n}^{\circ}$ 000676998.1995.8.19.0000, $1^{a}$ Câmara Cível, Rel. Des. Pedro Americo R. Gonçalves, julgado em 02 out. 1995; BRASIL. Tribunal de Justiça do Rio Grande do Sul. Agravo de Instrumento no 70000397927, 12a Câmara Cível, Rel. Des. Cézar Tasso Gomes, julgado em 16 dez. 1999; BRASIL. Superior Tribunal de Justiça. Conflito de Competência n $19.105 / M S$, Rel. Min. Sálvio de Figueiredo Teixeira, 2a Seção, julgado em 11 nov. 1998, DJ 15 mar. 1999 ; BRASIL. Superior Tribunal de Justiça. Recurso Especial n 158.193/AM, Rel. Min. Antônio de Pádua Ribeiro, $3^{\text {a }}$ Turma, julgado em 05 set. 2000, DJ 23 out. 2000.

17 A título de exemplo, v. BRASIL. Tribunal de Justiça do Estado do Rio de Janeiro. Apelação $\mathrm{n}^{\circ} 0004807-$ 98.1999.8.19.0000, Rel. Des. José Mota Filho, 15ª Câmara Cível, julgado em 24 nov. 1999; BRASIL. Tribunal de Justiça do Estado do Rio de Janeiro. Apelação nº 0001158-62.1998.8.19.0000, Rel. Des. Antônio Eduardo Ferreira Duarte, 13 ${ }^{a}$ Câmara Cível, julgado em 19 mai. 1998; BRASIL. Superior Tribunal de Justiça. Recurso

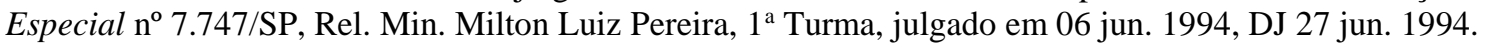


Revista da Faculdade de Direito-RFD-UERJ - Rio de Janeiro, n. 29, jun. 2016

Judiciário $^{18}$. Por outro lado, o debate sobre a tutela das uniões homoafetivas percorreu uma longa trajetória de conquistas nas instâncias inferiores antes de ser decidida no STF ${ }^{19}$.

É interessante notar que, há pouco tempo atrás, as questões envolvendo direitos habitualmente demoravam a ser decididas no STF. Por exemplo, a discussão sobre os expurgos econômicos das poupanças levou um tempo considerável para chegar ao STF (MOURA; LAZZARINI, 2016).

Paralelamente, parece legítimo intuir que a atuação do STF no domínio do direito da burocracia facilitou politicamente um movimento de verticalização do controle de constitucionalidade. Esse movimento, que se operou ao longo de vários anos, aconteceu com o suporte dos Poderes Executivo e Legislativo, que tinham interesse em concentrar no Supremo a validade das políticas que implementavam. Quando foram decididas as diversas reformas constitucionais e legais que promoveram um progressivo aumento no poder do STF, a cúpula do Judiciário não era vista como uma ameaça pelos poderes Executivo e Legislativo. Vale lembrar que a Ação Declaratória de Constitucionalidade, criada em 1993, foi idealizada como uma ferramenta de governabilidade, e não de tutela da Constituição. O objetivo dessa ação era precisamente permitir que o STF pudesse estancar, rapidamente, movimentos de declaração de inconstitucionalidade de políticas e reformas instituídas pelo governo nas instâncias inferiores. $\mathrm{O}$ efeito vinculante, inicialmente atribuído apenas a essa modalidade de ação, visava exatamente a evitar que decisões espalhadas declarando a invalidade da legislação federal comprometessem a governabilidade e os projetos do Executivo $^{20}$. Outro indício de que a progressiva concentração de poder na cúpula do Judiciário buscava dar maior efetividade ao controle do direito da burocracia, e não à proteção dos direitos fundamentais,

\footnotetext{
${ }^{18}$ Sobre a evolução da união estável no ordenamento jurídico brasileiro, v. Tepedino (2004).

${ }^{19}$ Uma análise do movimento LGBT no Brasil, do cenário que levou à decisão do Supremo Tribunal Federal, em 2011, e da conjuntura pós-decisão pode ser conferido em Gomes (2014, p. 90-112). Ainda sobre o histórico que levou ao julgamento pelo STF e análises acerca da decisão, v. Barroso (2013b), Nigro (2012), Nonato (2011) e Silva, F. (2003).

${ }^{20}$ Como destaca Clèmerson Merlin Clève, a ADC foi criada num cenário em que se presenciava a multiplicação de processos sobre questões coletivas e individuais, uma intensa atividade legiferante e o desencontro de decisões judiciais. Além disso, resolvida uma lide pelo STF em sede de Recurso Extraordinário e comunicado o Senado Federal para dar eficácia erga omnes à decisão, o legislativo se recusava a suspender o ato impugnado. Assim, "sem a suspensão do ato impugnado, e porque na questão em apreço não houve provocação da fiscalização abstrata, terá o Supremo de processar milhares de recursos extraordinários interpostos pela União apenas para o fim de protelar a solução definitiva (e suas consequências) de todas as ações" (CLÈVE, 2000, p. 276). Com isso, foi proposta e aprovada uma Emenda Constitucional criando a ADC, complementando o modelo brasileiro de controle abstrato de constitucionalidade. Com a nova ação, "ocorrente dissídio a respeito da legitimidade de uma lei ou ato normativo federal, [é possível] levar desde logo a questão constitucional ao Supremo Tribunal Federal para que este, exercendo a guarda da Constituição, a resolva de modo definitivo (com eficácia erga omnes e efeito vinculante)" (Idem, 2000, p. 282).
} 
foi o fato de que, quando a ação de descumprimento de preceito fundamental, prevista pela Constituição de 1988, foi finalmente regulada (Lei $\mathrm{n}^{\circ}$ 9.882/99), o então presidente da república vetou o dispositivo que permitiria que questões de direitos fundamentais chegassem ao Supremo diretamente por iniciativa dos $\operatorname{lesados}^{21}$. Mais recentemente, o ciclo de concentração se completou com a introdução da Súmula Vinculante e da Repercussão Geral, que permite que o tribunal suspenda a tramitação dos processos em curso, paralisando a apreciação do direito por outras esferas do Judiciário ${ }^{22}$.

A partir dos anos 2000, podemos notar uma sensibilidade maior do Supremo em questões envolvendo direitos fundamentais. No entanto, vale notar que essa sensibilidade inicialmente se manifestou como uma sensibilidade no ponto de chegada, não como uma sensibilidade no ponto de partida nas discussões envolvendo direitos fundamentais. A preocupação com a tutela de direitos fundamentais apareceu em decisões que confirmavam argumentos e decisões tomados nas instâncias inferiores ou no Legislativo. São ilustrativas desse fenômeno as já citadas discussões sobre fornecimento de medicamentos e o reconhecimento da validade das ações afirmativas (ADPF $\mathrm{n}^{\circ}$ 186). Apesar de estas serem

\footnotetext{
${ }^{21}$ O Projeto de Lei 2.872/97, posteriormente convertido na Lei da ADPF, previa no inciso II do art. $2^{\circ}$ que "qualquer pessoa lesada ou ameaçada por ato do Poder Público" seria legitimada para propor ADPF. A Mensagem $n^{\circ} 1.807 / 99$ vetou tal inciso, sob a seguinte argumentação: "A disposição insere um mecanismo de acesso direto, irrestrito e individual ao Supremo Tribunal Federal sob a alegação de descumprimento de preceito fundamental por "qualquer pessoa lesada ou ameaçada por ato do Poder Público". A admissão de um acesso individual e irrestrito é incompatível com o controle concentrado de legitimidade dos atos estatais - modalidade em que se insere o instituto regulado pelo projeto de lei sob exame. A inexistência de qualquer requisito específico a ser ostentado pelo proponente da argüição e a generalidade do objeto da impugnação fazem presumir a elevação excessiva do número de feitos a reclamar apreciação pelo Supremo Tribunal Federal, sem a correlata exigência de relevância social e consistência jurídica das argüições propostas. Dúvida não há de que a viabilidade funcional do Supremo Tribunal Federal consubstancia um objetivo ou princípio implícito da ordem constitucional, para cuja máxima eficácia devem zelar os demais poderes e as normas infraconstitucionais. De resto, o amplo rol de entes legitimados para a promoção do controle abstrato de normas inscrito no art. 103 da Constituição Federal assegura a veiculação e a seleção qualificada das questões constitucionais de maior relevância e consistência, atuando como verdadeiros agentes de representação social e de assistência à cidadania. Cabe igualmente ao Procurador-Geral da República, em sua função precípua de Advogado da Constituição, a formalização das questões constitucionais carentes de decisão e socialmente relevantes. Afigura-se correto supor, portanto, que a existência de uma pluralidade de entes social e juridicamente legitimados para a promoção de controle de constitucionalidade - sem prejuízo do acesso individual ao controle difuso - torna desnecessário e pouco eficiente admitir-se o excesso de feitos a processar e julgar certamente decorrentes de um acesso irrestrito e individual ao Supremo Tribunal Federal. Na medida em que se multiplicam os feitos a examinar sem que se assegure sua relevância e transcendência social, o comprometimento adicional da capacidade funcional do Supremo Tribunal Federal constitui inequívoca ofensa ao interesse público. Impõe-se, portanto, seja vetada a disposição em comento.".

${ }^{22}$ A Emenda Constitucional $\mathrm{n}^{\circ}$ 45/2004, conhecida como emenda da Reforma do Judiciário, inseriu o art. 103-A na Constituição Federal de 1988, dispositivo que trata da Súmula Vinculante. O instituto foi regulamentado pela Lei $\mathrm{n}^{\circ} 11.417 / 06$. A mesma Emenda Constitucional introduziu o $\S 3^{\circ}$ no art. 102 da Constituição, prevendo a repercussão geral como requisito de admissibilidade do Recurso Extraordinário. Sobre o tema, v. Barroso (2011, pp. 101-110 e 131-143), Rodrigues Filho (2015), Dantas (2012) e Jansen (2005).
} 
decisões do STF muito conhecidas e celebradas em matéria de direitos, elas constituem os capítulos finais de longos embates constitucionais, e não seus prefácios. De forma similar, as decisões sobre a Lei de Biossegurança ${ }^{23}$ e sobre a interrupção da gestação de anencéfalos ${ }^{24-25}$ são, também, decisões de confirmação e estabilização, caracterizando pontos de chegada. As decisões ativistas que constituem pontos de chegada assumem contornos particulares. Elas

${ }^{23} \mathrm{O}$ acórdão em que se decidiu pela constitucionalidade da Lei de Biossegurança (Lei ${ }^{\circ}$ 11.105/05) - que regulamenta pesquisas com células-tronco embrionárias, permitindo sua utilização para fins terapêuticos e científicos quando estas forem extraídas de embriões resultantes de fertilização in vitro congelados há mais de três anos ou inviáveis, desde que haja autorização dos genitores -, teve grande repercussão no sentido do fortalecimento do papel do STF como guardião dos direitos e das promessas da sociedade como um todo. Também deixou claro que as questões morais controvertidas passaram a integrar a pauta do Tribunal. Sustentava o autor que a lei seria inconstitucional, pois a realização de estudos com células obtidas de embriões humanos violaria o direito à vida e o princípio constitucional da dignidade da pessoa humana, uma vez que a vida teria como marco inicial o momento da fecundação. O Supremo, porém, por seis votos a cinco, rejeitou a alegação de inconstitucionalidade e manteve a lei sem ressalvas. O voto do Ministro Relator Carlos Britto foi o prevalecente e sustentou que os preceitos impugnados não ofendem o direito à vida ou o cânone da dignidade da pessoa humana: a Constituição não oferece uma resposta definitiva quanto ao momento em que se inicia a vida humana, a qual resulta de um processo complexo que compreende vários estágios (fecundação, nidação e gestação), sendo que cada um deles desfruta de uma proteção diferenciada pelo Estado. Partindo dessa premissa, sustentou-se que o zigoto que se encontra fora do útero materno corresponde a uma etapa ainda incipiente e potencial da formação da pessoa, razão por que não tem proteção jurídica equivalente àquela dispensada à pessoa natural formada. Ponderou também que a Constituição tutela o direito à saúde e determina o incentivo à pesquisa científica, o que confere respaldo à utilização das células-tronco embrionárias para o tratamento de doenças. (BRASIL. Supremo Tribunal Federal. Ação Direta de Inconstitucionalidade no 3510/DF, Tribunal Pleno, Rel. Min. Ayres Britto, julgado em 29 ago. 2008, publicação em 28 ago. 2010).

${ }^{24}$ Em 2012, na ADPF no 54, o STF afirmou a inconstitucionalidade da interpretação pela qual a interrupção da gravidez de feto anencéfalo configuraria conduta tipificada por dispositivos referentes ao aborto presentes no Código Penal. Afirmando a laicidade estatal, a liberdade sexual e reprodutiva da mulher, além da necessidade de proteger sua saúde, sua dignidade e seu direito à autodeterminação, o Supremo acolheu o pedido da Confederação Nacional dos Trabalhadores na Saúde (CNTS), que defendia que apenas o feto com capacidade potencial de vida extrauterina poderia ser sujeito passivo do crime de aborto.

${ }^{25} \mathrm{E}$, hoje, esse problema ainda é presente nas instâncias inferiores em relação às deformações que não se enquadram na anencefalia. Ainda hoje há uma divisão entre os juízes que deferem e os juízes que indeferem a interrupção da gestação de fetos inviáveis. Para as mulheres que passam por essas gestações em que o feto tem problemas graves diversos da anencefalia, a permissão para abortar ainda é uma loteria.

Sobre outras anomalias do feto incompatíveis com a vida extrauterina diferentes da anencefalia, v. Diniz (2016) e Gazzola; Melo (2015).

Como exemplos de casos em que os Tribunais permitiram a interrupção da gravidez em casos de malformações diferentes da anencefalia, v. BRASIL, Tribunal de Justiça de São Paulo, Mandado de Segurança n $^{\circ}$ 209187192.2014.8.26.0000, 13 ${ }^{\mathrm{a}}$ Câmara de Direito Criminal, Rel. Des. De Paula Santos, julgado em 24 jul. 2014, publicação 13 ago. 2014; BRASIL, Tribunal de Justiça do Rio Grande do Sul, Apelação Crime no 70055089049 , $1^{a}$ Câmara Criminal, Relator Des. Julio Cesar Finger, julgado em 26 jun. 2013, publicação em 10 jul. 2013; BRASIL, Tribunal de Justiça do Rio de Janeiro, Habeas Corpus n ${ }^{\mathrm{o}}$ 0046983-67.2014.8.19.000, $7^{\mathrm{a}}$ Câmara Criminal, Rel. Des. Siro Darlan de Oliveira, julgado em 23 set. 2014, publicação 26 set. 2014.

Em outros casos, porém, os tribunais permitiram a interrupção da gestação. Neste sentido, v. BRASIL, Tribunal de Justiça do Rio de Janeiro, Habeas Corpus n ${ }^{\circ}$ 0013332-44.2014.8.19.0000, $1^{\text {a }}$ Câmara Criminal, Rel ${ }^{\mathrm{a}}$. Des ${ }^{\mathrm{a}}$. Sandra Kayat Direito, julgado em 25 mar. 2014, publicação 28 mar. 2014; BRASIl, Tribunal de Justiça de São Paulo, Mandado de Segurança $\mathrm{n}^{\circ}$ 2107596-87.2015.8.26.0000, 12 $2^{\text {a }}$ Câmara de Direito Criminal, rel. Des. Vico Mañas, julgado em 29 jul. 2015, publicação em 01 ago. 2015; BRASIL, Tribunal de Justiça do Rio de Janeiro, Habeas Corpus $\mathrm{n}^{\circ}$ 0023285-95.2015.8.19.0000, 8 Câmara Criminal, Rel. Des. Claudio Tavares de O. Junior, julgado em 27 mai. 2015, publicação em 29 mai. 2015. 
não partem de argumentos colocados por um único ator jurídico, mas são produto de um conjunto de teses e antíteses que formam um rico arsenal de argumentos. Ao mesmo tempo, as decisões tomadas a partir de atos legislativos ou de embates judiciais iniciados nas instâncias inferiores possuem a vantagem de resolver tópicos que já transitavam na esfera estatal há algum tempo, gerando a oportunidade de amadurecimento da discussão, bem como a participação de vários agentes institucionais.

Mais recentemente, descortina-se um terceiro movimento ${ }^{26}$, em que as discussões já se iniciam no STF antes mesmo de serem debatidas no legislativo ou nas instâncias inferiores, viabilizando que o tribunal exerça um ativismo de ponto de partida. A $\operatorname{ADPF} n^{\circ} 347$, que suscitou a existência de um estado de coisas inconstitucional nos presídios ${ }^{27}$, é um exemplo emblemático desse caminho, porquanto constitui um atalho que permite que debates que envolvem direitos fundamentais comecem diretamente na cúpula do Judiciário, que tem os instrumentos jurídicos para formular decisões de maior abrangência e com potencial transformador mais imediato.

Outro exemplo é a ação em que se debateu o financiamento de campanhas eleitorais (ADI $n^{\circ} 4651$ ), na qual foram atacados dispositivos da Lei das Eleições (Lei $n^{\circ}$ 9.504/97) e da Lei dos Partidos Políticos (Lei 9.096/95) com o intuito de declarar a inconstitucionalidade da doação por pessoas jurídicas a campanhas eleitorais e a partidos políticos. Além disso, requereu-se que o Congresso Nacional fosse instado a editar legislação limitando as doações por pessoa natural e o uso de recursos próprios pelos candidatos em campanha eleitoral. Nesses casos, as decisões do STF não representam a síntese de um longo debate travado no legislativo e em outras instâncias judiciais. Ao contrário, o tribunal é chamado a dar uma resposta inicial, abstrata e, ao mesmo tempo, definitiva sobre a interpretação da constituição. Trata-se de uma fórmula que representa um coeficiente de ativismo mais concentrado e com maior impacto sobre a agenda política, porquanto são minimizadas as chances de serem colocados em ação mecanismos de freios e contrapesos. Além disso, o timing da resposta judicial não segue um fluxo institucional pautado por forças heterogêneas, mas é ditado

\footnotetext{
${ }^{26}$ Cabe notar que a Clínica de Direitos Fundamentais da UERJ - que tem, dentre seus objetivos, "contribuir para a ampliação da proteção aos direitos fundamentais no Brasil" e "apoiar a sociedade civil em ações relacionadas aos direitos fundamentais, mediante a prestação de assessoria jurídica especializada" - tem sido um agente impulsionador dessas ações. Para mais informações, confira o sítio eletrônico da Clínica UERJ Direitos, onde está disponível o ato de fundação: <http://uerjdireitos.com.br〉. Acesso em: 04 jun. 2016.

27 Sobre o tema veja-se, Pereira (2015) e Campos (2015).
} 
diretamente pelo próprio STF, que controla sua agenda ${ }^{28}$, podendo deixar a questão amadurecer ou enunciar uma decisão rapidamente. Nesse sentido, sob a ótica do litígio estratégico de direitos humanos, a judicialização operada diretamente no STF possui vantagens, tais como permitir uma solução mais célere, bem como maior facilidade, em tese, de influenciar apenas onze juízes. A desvantagem, porém, é a diminuição do número de forças envolvidas, que promove um aumento do déficit democrático da decisão, bem como a possibilidade de uma decisão desfavorável - ou de uma não-decisão - cristalizar uma situação de desproteção de direitos, tornando-a mais difícil de reverter.

Paralelamente, há dois tipos de percursos que as teses envolvendo direitos fundamentais judicializados podem percorrer. Os argumentos pela proteção dos direitos podem chegar ao Supremo a partir de uma força centrípeta, quer dizer, eles podem despontar na sociedade, ser pleiteados nas instâncias inferiores e, pela via do controle difuso ou de uma ação de controle abstrato tardiamente ajuizada ou julgada, ser apreciados pelo STF. Quando isso acontece, normalmente a discussão já está mais amadurecida. É o que ocorreu, por exemplo, em relação à judicialização das prestações de saúde e às cotas para afrodescendentes. Esses argumentos podem também encetar um movimento centrífugo, ao serem levados diretamente ao STF pelos legitimados e, a partir daí, espraiarem-se para a sociedade e para o discurso jurídico. Um exemplo emblemático desse processo é a discussão sobre a legitimidade constitucional do financiamento de campanhas por empresas, travada, essencialmente, naquela Corte. Em vários casos, esse movimento pode ser bilateral ou de mão dupla, como ocorreu na discussão sobre as uniões homoafetivas. Se, de um lado, a decisão do STF é um ponto de chegada quanto a um tema que por muitos anos foi debatido no Judiciário, de outro, ela é um ponto de partida em relação à abrangência que conferiu ao direito de igualdade e ao viés pedagógico importantíssimo que exerceu na sociedade e para debelar os focos de resistência que existiam dentro do próprio Poder Judiciário. A decisão do STF promoveu uma mudança de paradigma ao rejeitar os argumentos que embasavam essa oposição ${ }^{29}$.

Mas é necessário, também, notar que, mesmo na América Latina, o STF não se sobressai ainda como um Tribunal prioritariamente de proteção dos direitos fundamentais. Como destaca Alonso Freire em estudo recente, a Corte Colombiana e a Corte Costarriquense

\footnotetext{
${ }^{28}$ Sobre o controle a agenda do Supremo Tribunal Federal, v. Oliveira (2016).

${ }^{29}$ Note-se, inclusive, que se apontou certa artificialidade na unanimidade (ARGUELHES; RIBEIRO, 2012).
} 
avançaram drasticamente e em poucos anos na proteção dos direitos humanos em contraposição aos outros países na América Latina, incluindo aí o Brasil:

\begin{abstract}
Em avaliações comparativas, vários estudiosos têm concluído que as Cortes da Costa Rica e da Colômbia são as que se mostram mais capazes e dispostas tanto a (i) proteger direitos individuais como a (ii) arbitrar conflitos entre os Poderes. De acordo com esses estudos, a pior Corte em ambos os aspectos é a da Bolívia. Ainda segundo eles, as Cortes do Brasil, Chile e México, embora tenham arbitrado com relativo sucesso os conflitos entre os poderes do Estado, seriam menos eficazes na proteção de direitos fundamentais, especialmente os individuais, conquanto gozem de alto nível de independência. Aponta-se, contudo, que a Corte do Chile tem desempenhado cada vez mais os dois papéis nos últimos anos. Por outro lado, a Corte da Argentina, às vezes, desempenha ambos os papéis; ocasionalmente, nenhum. (FREIRE, 2015, p. 594-595)
\end{abstract}

Com efeito, pesquisas recentes indicam que o grande cliente do Supremo são as grandes corporações econômicas e o Estado (COSTA; BENVINDO, 2014; FALCÃO; CERDEIRA, 2011). Portanto, ainda que essas ações relacionadas aos direitos fundamentais tenham uma grande visibilidade midiática, do ponto de vista quantitativo, elas jamais foram o ponto de ação prioritária do Supremo. Esse quadro tende a se agravar, considerando que nos últimos anos os julgamentos criminais envolvendo a corrupção na política arrebataram a pauta do STF. Igualmente, a crise presidencial e o processo de impeachment desencadearam uma série de julgamentos urgentes que, somados às muitas outras competências do STF, tendem a manter a proteção de direitos fundamentais como uma pauta secundária.

\title{
2 A VERTICALIZAÇÃO DA JURISDIÇÃO CONSTITUCIONAL E SUA INFLUÊNCIA SOBRE A PROTEÇÃO DOS DIREITOS FUNDAMENTAIS
}

Um segundo ponto merece ser explorado: em que medida a intensa concentração de poder no Supremo pode colaborar para proteger direitos fundamentais? E em que medida ela pode dificultar a proteção desses direitos?

É possível, inicialmente, colocar a questão sob um ângulo mais geral, indagando: em que medida o protagonismo do Poder Judiciário como um todo contribui para a proteção dos direitos? Esse ponto já foi parcialmente explorado na introdução, mas vale retomá-lo de forma mais concreta. 
Revista da Faculdade de Direito-RFD-UERJ - Rio de Janeiro, n. 29, jun. 2016

A proteção jurídica dos direitos fundamentais pode ser encarada com algum otimismo nos cenários em que se verifique que os legisladores e os juízes são aptos a atuar como facilitadores da emancipação de grupos oprimidos. Os modelos de proteção legal, em verdade, não são autossuficientes, mas dependem de uma série de fatores contingentes e externos ao Direito. A eficiência da proteção jurídica de direitos fundamentais pressupõe um sistema de construção e aplicação das normas permeado pelo pluralismo e sensível às demandas por inclusão. Isso não é simples, considerando que os sistemas jurídicos e seus operadores tendem a refletir e reproduzir as relações de opressão presentes na sociedade.

Uma série de fatores torna imperioso calibrar o otimismo quanto à judicialização de direitos fundamentais. É preciso ter em conta que o próprio constitucionalismo promove o entrincheiramento de determinadas visões políticas que, a despeito de se apresentarem como universais, são particulares ${ }^{30}$. O Direito promove a tradução dos discursos sociais e de uma série de visões heterogêneas da sociedade para uma linguagem elitizada e homogênea, que, apenas por isso, revela-se muitas vezes excludente. Nesse sentido, deve-se levar a sério o risco apontado pelos críticos à juridicização das liberdades, no sentido de que a redução dos cidadãos à figura do sujeito de direito pode inibir seus impulsos construtivos como agentes democráticos. Paralelamente, o Direito pode ser "o fenômeno inicial da irracionalidade racional" (Adorno) (FRANKENBERG, 2007, p. 268), porquanto encerra um modelo de racionalidade que não assegura que não serão evitados resultados irracionais, injustos ou até mesmo brutais. O sistema carcerário brasileiro é um exemplo emblemático de como as fórmulas racionais do discurso jurídico podem produzir a barbárie ${ }^{31}$.

Outro obstáculo que deflui do ato de traduzir lutas sociais na linguagem dos direitos é a limitação imposta pela circunstância de que o próprio sistema judicial, em função de sua posição institucional e das fórmulas de recrutamento, tende a reproduzir os comportamentos hegemônicos, perpetuando, pela via hermenêutica, desigualdades estruturais. Exemplo

30 "O que proponentes (legais) descrevem como uma alternativa para a política é, na realidade, o entrincheiramento de uma visão política particular" (PETTER, 1989, p.161).

${ }^{31}$ Neste sentido, o relatório produzido pela CPI do Sistema Carcerário aponta: "O Brasil conta com excelente aparato jurídico relativo ao Direito Penitenciário. A Constituição Federal contém importantes princípios gerais referentes às mulheres, aos direitos dos presos e à pena. A Lei de Execução Penal (LEP) é uma das mais avançadas do mundo e está em vigor há 24 anos. Há várias outras leis bastante precisas. (...) Apesar da excelente legislação e da monumental estrutura do Estado Nacional, os presos no Brasil, em sua esmagadora maioria, recebem tratamento pior do que o concedido aos animais: como lixo humano." O Relatório demonstra, por fotos e vídeos, "os crimes que o Estado Brasileiro, através de sucessivos governos, tem praticado contra os seus presos e a sociedade. Ao invés de recuperar quem se desviou da legalidade, o Estado embrutece, cria e devolve às ruas verdadeiras feras humanas." (BRASIL, 2009, p. 191-192). 
emblemático da reprodução das relações de assimetria no processo judicial são as questões de gênero, que tendem a ser interpretadas de forma machista pelo Judiciário (KAUFMAN; LINDQUIST, 1995, p. 116). Nos casos de violência doméstica, estupro e assédio sexual, por exemplo, muitas vezes é o comportamento da vítima que é avaliado e julgado. A dificuldade do sistema jurídico de lidar com essas questões passa tanto pelo déficit estrutural nos canais de acesso à justiça, como pelas interpretações e leituras distorcidas que os agentes de poder tendem a reproduzir ${ }^{32}$.

Paralelamente, não se pode perder de vista que, quando juízes se colocam em posição de heroísmo constitucional ${ }^{33-34}$, arrogando-se o papel de tutelar os direitos dos oprimidos e excluídos, reproduzem e reforçam a dinâmica assimétrica que reduz os cidadãos à posição de sujeitos processuais. Por essas razões, é preciso estar ciente de que, por mais que o constitucionalismo abrace um projeto inclusivo, ele sempre dependerá de uma estrutura que é, em si mesma, opressiva, porque provém do Estado. Isso impõe que as fórmulas de judicialização de direitos não desconsideram as falhas e desvios que advêm da própria adoção de um modelo de proteção legal.

Passando para o plano mais concreto das instituições brasileira, cabe discutir de que maneira a progressiva concentração de poder no STF, ou seja, a intensa verticalização da jurisdição constitucional contribui para a proteção dos direitos humanos, bem como de que maneira ela debilita essa proteção.

\footnotetext{
${ }^{32}$ Sobre as deficiências de aplicação da Lei Maria da Penha e as políticas públicas de combate à violência contra a mulher, v. Sardenberg; Grossi (2015) e Martins; Cerqueira; Matos (2015). V., ainda, a Recomendação Geral no 33, de 2015, da Convenção das Nações Unidas Sobre a Eliminação de Todas as Formas de Discriminação contra as Mulheres, que trata do acesso da mulher à justiça e destaca que tal acesso e a participação igualitária das mulheres no judiciário e em outros mecanismos de aplicação da lei são elementos fundamentais do Estado de Direito e da boa governança. Examina, ainda, "as obrigações dos Estados partes para assegurar que as mulheres tenham acesso à justiça. Essas obrigações incluem a proteção dos direitos das mulheres contra todas as formas de discriminação com vistas a empoderá-las como indivíduos e titulares de direitos". A recomendação também pontua a existência de obstáculos e restrições que impedem as mulheres de realizar seu direito de acesso à justiça - obstáculos estes que ocorrem em um contexto estrutural de "discriminação e desigualdade, devido a fatores como estereótipos de gênero, leis discriminatórias, discriminação interseccional ou composta, requisitos, procedimentos e práticas em matéria probatória, e à falha em sistematicamente assegurar que os mecanismos judiciais sejam física, econômica, social e culturalmente acessíveis a todas as mulheres" (ORGANIZAÇÃO DAS NAÇÕES UNIDAS, 2015).

${ }^{33}$ Sobre heroísmo constitucional, v. Sunstein (2015) e Waldron (2016).

${ }^{34}$ Ingeborg Maus (2000) pontua que ideias aparentemente boas quanto à garantia judicial de liberdades podem disfarçar a irracionalidade e o arbítrio cerceador da autonomia dos indivíduos e da soberania popular. Os setores sociais tornam-se cada vez mais sujeitos à intervenção casuísta do Estado e a autonomia dos indivíduos é colocada em cheque e cria-se, assim, uma sociedade órfã, facilmente conduzida pelo aparato estatal, no qual inclui-se o poder judiciário.
} 


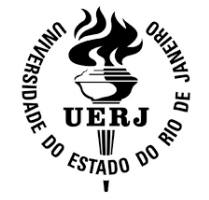

Um benefício relacionado aos julgamentos sobre direitos fundamentais travados no STF é a sua maior visibilidade, que carreia maior cobrança e vigilância da sociedade e da mídia $^{35}$. Em certos cenários, a circunstância de o julgamento ser televisionado e de o esforço de persuasão recair sobre apenas onze juízes pode funcionar como um elemento de facilitação da proteção dos direitos fundamentais.

Esses elementos se verificam de forma particularmente clara quando grupos que possuem interlocução em todas as camadas sociais estão engajados na questão, como ocorreu em relação às uniões homoafetivas. Nesse julgamento, parece legítimo intuir que a adesão da mídia e da elite intelectual à tese da validade do reconhecimento das uniões homoafetivas fez diferença no processo de convencimento do $\mathrm{STF}^{36}$. No entanto, é preciso ter em conta que a validade das uniões homoafetivas é um tema que afeta de forma semelhante vários setores econômicos. A discriminação relacionada à orientação sexual não recai apenas sobre grupos marginalizados, já que as relações homoafetivas acontecem em todas as classes sociais. Por isso, não é tão fácil reproduzir a dinâmica da pressão midiática e das elites em outros temas envolvendo direitos fundamentais, como, por exemplo, direitos dos indígenas, de comunidades quilombolas ou direitos dos presos.

Outra vantagem que a tutela diretamente no STF encerra é a segurança jurídica que advém da definitividade da decisão, bem como seu caráter vinculante. Há, ainda, o viés pedagógico que essas decisões assumem, pois sua grande visibilidade faz com que funcionem como ferramentas não apenas de efetivação, mas de conscientização e informação a respeito dos direitos.

De outra parte, há uma série de desvantagens na escolha do STF como via prioritária de tutela dos direitos humanos. A mais importante é o tempo do julgamento. A absurda concentração de competências do STF tem duas consequências negativas sobre a proteção dos direitos fundamentais. A primeira é que o julgamento dessas ações depende de um compromisso do presidente da corte e dos ministros com essas causas, considerando a enorme discricionariedade de que dispõem para definir sua agenda. A segunda é que, mesmo que os ministros optem por julgar questões de direitos humanos, as urgências impostas pela pauta penal e política muitas vezes sequestram o tempo da corte e subvertem a ordem de prioridade,

\footnotetext{
${ }^{35}$ Muitos trabalhos têm abordado a influência da opinião pública nos julgamentos do STF. Veja-se, por exemplo, Mello (2015), Novelino (2013) e Pereira (2012).

${ }^{36}$ É interessante notar que Baum e Devins (2010) ressaltam, sobre a suprema corte norte-americana, que a posição da elite importa mais que a opinião pública em geral.
} 
Revista da Faculdade de Direito-RFD-UERJ - Rio de Janeiro, n. 29, jun. 2016

como aconteceu, por exemplo, no curso da crise política e do processo de impeachment de 2016.

O principal obstáculo que a crescente concentração de poder no STF impõe à tutela dos direitos, porém, é o estreitamento dos canais de acesso. Ter uma causa decidida pelo STF não é uma empreitada fácil. No âmbito da jurisdição abstrata e concentrada, o acesso é limitado, primeiramente, pela lista de legitimados enunciada na Constituição e, em acréscimo, pela interpretação restritiva formulada pelo próprio STF. Na jurisdição constitucional difusa, fazer um Recurso Extraordinário chegar ao tribunal não é simples, seja pelos vários requisitos para a correta formulação jurídica da peça, seja pelas dificuldades operacionais de acompanhar o recurso e o julgamento no Distrito Federal. Ao mesmo tempo, a prática judiciária nos tribunais superiores é marcada pela presença de uma advocacia de elite altamente especializada, que atua sobretudo nas questões com relevância financeira e não está acessível para os grupos marginalizados. A verticalização da jurisdição constitucional, em última análise, tornou a proteção dos direitos fundamentais mais distante dos seus titulares.

Nesse contexto, assume enorme importância o aperfeiçoamento do sistema de proteção difuso. As principais vantagens de iniciar as discussões envolvendo direitos fundamentais pelas instâncias de base é a maior capilaridade no acesso ao Poder Judiciário, que facilita a demanda e aumenta a chance de haver maior agilidade na resposta. Se aliarmos essa característica à presença de defensorias públicas fortalecidas ${ }^{37}$ - é possível ampliar a cultura de direitos em todos os níveis no discurso jurídico. Uma gramática de direitos que se espraiou na sociedade a partir da atuação do Judiciário em primeira instância é a jurisprudência formada em Direito Previdenciário, em Direito do Consumidor e em matéria de prestações de saúde. É interessante notar, porém, que não se formou uma cultura semelhante

\footnotetext{
37 Em 2014, nos Embargos de Declaração no Agravo de Instrumento 598.212, recebidos como recurso de agravo, o STF reconheceu omissão estatal que compromete e frustra direitos fundamentais de pessoas necessitadas, transformando seus direitos e liberdades fundamentais em proclamações inúteis, convertendo-os em expectativas vãs. Uma vez que todos tem o direito a ter direitos, é de fundamental importância a atividade da Defensoria Pública no sentido de viabilizar o acesso dos necessitados à orientação jurídica integral e à assistência judiciária gratuitas, concretizando programa constitucional (art. 5 , LXXIV e art. 134, ambos da Constituição Federal de 1988). Diante da inescusável omissão estatal, é lícito ao Poder Judiciário adotar medidas destinadas a efetivar políticas públicas. E não há a possibilidade de se invocar a reserva do possível na perspectiva da teoria dos custos dos direitos, pois há injusto inadimplemento de deveres estatais na prestação constitucionalmente imposta ao Estado. Com base nisto, o STF deu parcial provimento ao recurso de agravo para afirmar que a procedência da Ação Civil Pública ajuizada pelo MPE/PR restringe-se à criação e à implantação da Defensoria Pública na comarca de Apucarana/PR - alterando, em parte, o entendimento proferido no AI 598.212, que restabeleceu sentença de primeira instância que determinara a instalação de defensoria pública no estado do Paraná no prazo de 6 meses. (BRASIL. Supremo Tribunal Federal. AI 598212 ED, Segunda Turma, Relator Min. Celso de Mello, julgado em 25 mar. 2014, DJe 24 abr. 2014).
} 
em matéria de liberdades existenciais, tais como liberdade de expressão e manifestação. Possivelmente, a ausência de uma ação específica para tutela de direitos fundamentais, de acesso facilitado e trâmite simplificado, contribui para que a nossa cultura de direitos tenha avançado apenas em relação àqueles que possuem uma dimensão prestacional ou econômica.

\section{OS DIREITOS FUNDAMENTAIS COMO PAUTA PRIORITÁRIA DO JUDICIÁRIO: CANAIS DE ACESSO E EXERCÍCIO DA CIDADANIA}

Por fim, passo ao terceiro ponto: como tornar a tutela dos direitos fundamentais uma pauta prioritária do Judiciário? Poder-se-ia questionar se, em alguns temas, como liberdade de expressão, o STF é mais sensível do que a base do Judiciário, o que justificaria encará-lo como canal principal na sua proteção. No entanto, ainda que análises desse tipo possam ser levadas em consideração estrategicamente na hora de decidir o caminho a ser tomado para a propositura de ações específicas, elas não resolvem o problema de cimentar uma cultura de direitos no longo prazo. Para obter efeitos de médio prazo, as fórmulas processuais e o desenho institucional importam. O primeiro passo para pensar esse assunto é reconhecer e debater a dimensão política das normas processuais ${ }^{38}$. As regras processuais que pavimentam o acesso ao Judiciário constituem um dos pilares da política de direitos humanos do país.

Nesse contexto, as fórmulas de acesso ao Judiciário e as prioridades do sistema podem ser repensadas com o escopo de fortalecer a teia de proteção dos direitos fundamentais. Como acertadamente pontua Martha Minow:

\footnotetext{
"Regras procedimentais são uma espécie de andaime que sustenta o constante esforço de construir e reconstruir a justiça. Demasiada atenção à preservação do andaime perde o ponto do esforço. $\mathrm{O}$ andaime pode e deve se mover conforme a necessidade de um projeto maior. Ele deve ser estável o suficiente para se manter de pé, mas deve manter a capacidade de ser desmontado e remontado conforme necessário." (MINOW, 1998, p. 116)
}

No Brasil, o direito processual é debatido e ensinado nas universidades sob um foco predominantemente procedimental, com pouca reflexão sobre sua faceta política e sobre os impactos econômicos que as fórmulas processuais encerram. Há uma carência de análises que investiguem a fundo as preferências políticas e os interesses corporativos e econômicos que as

\footnotetext{
${ }^{38}$ Analisando a política no processo civil, veja-se Brescia; Ohanian (2013), Carrington (2010) e Minow (1998).
} 
regras de processo promovem. Um exemplo emblemático da dinâmica legislativa e acadêmica nessa seara foram os debates que resultaram na aprovação do novo Código de Processo Civil. As discussões focaram predominantemente na promessa de eficiência e de democratização do processo civil. No entanto, boa parte das mudanças mais significativas que se operaram têm acentuado viés corporativo. São exemplares desse perfil corporativista as detalhadas regras sobre honorários (art. 85), a contagem de prazo em dias úteis (art. 219), a imposição de presença de advogados durante as fases de mediação e conciliação (art. 334, § $9^{\circ}$ ) e a longa lista de autoridades que dispõem da prerrogativa de serem ouvidas em sua própria residência (art. 454).

Nesse cenário, o detalhado sistema processual brasileiro, supostamente reformado e modernizado, ainda consagra uma série de ações e procedimentos especiais com as mais variadas finalidades, mas não contempla uma ação especial de tutela de direitos fundamentais de perfil simplificado. A teia processual brasileira e o conjunto de requisitos impostos para litigar encerra, em última análise, uma escolha política em desfavor dos direitos fundamentais existenciais. Seria possível objetar que essa afirmação é exagerada, considerando que a própria Constituição de 1988 consagrou um amplo leque de remédios constitucionais voltados para a salvaguarda de direitos. No entanto, essa ampla variedade não corresponde à facilidade e à simplicidade que deveria caracterizar esse tipo de ação. A única ação efetivamente simplificada e amplamente acessível é o habeas corpus, que se restringe à proteção da liberdade ambulatorial. No limiar do regime republicano, Ruy Barbosa engendrou a conhecida doutrina brasileira do habeas corpus, que buscava exatamente dilatar o alcance daquela ação permitindo que fosse utilizada para as diversas formas de ameaça às liberdades ${ }^{39}$. Uma reforma efetivada em 1926 suprimiu essa possibilidade ${ }^{40}$ e hoje, quase um século depois, não

\footnotetext{
39 A Constituição de 1891 era baseada na teoria liberal norte-americana importada para o Brasil por Ruy Barbosa. Na linha liberal de pensamento, constitucionalizou-se o habeas corpus no $\S 22$ do art. 72, que não limitava o cabimento do writ à liberdade de locomoção. Previa o dispositivo: "Dar-se-á o habeas corpus, sempre que o indivíduo sofrer ou se achar em iminente perigo de sofrer violência ou coação por ilegalidade ou abuso de poder". Assim, Ruy Barbosa impulsionou o desenvolvimento da doutrina brasileira do habeas corpus, que foi aplicada também pelo STF. O remédio constitucional foi ampliado para proteger liberdades em situações de arbitrariedade estatal, e não apenas a liberdade de locomoção (SARMENTO, 2010, p. 17-23).

40 A Emenda de 1926 à Constituição de 1891, única emenda durante sua vigência, tinha caráter centralizador e anti-liberal e, neste sentido, deu fim à doutrina brasileira do habeas corpus ao restringir o cabimento do instrumento apenas a casos de constrangimento ou ameaça à liberdade de locomoção. Interessante notar que, mesmo após a reforma constitucional, a jurisprudência tentou resistir, entendendo ser cabível o writ sempre que a liberdade de locomoção fosse um "direito condição para o exercício de outros direitos", mas, em virtude da restrição do texto constitucional, esta posição restou enfraquecida (SOUZA, 2008, p. 80). Após a emenda, o $\$ 22$ do art. 77 passou a ter a seguinte redação: "Dar-se-ha o habeas-corpus sempre que alguém soffrer ou se achar em
} 
existe uma fórmula processual que corresponda ao que se buscou construir com referida doutrina. As ações de tutela que existem na Colômbia ${ }^{41}$ e na Costa Rica ${ }^{42}$ guardam maior semelhança com a doutrina defendida por Ruy Barbosa do que qualquer outro remédio processual existente no sistema brasileiro. Essas ações contemplam a mesma simplicidade e facilidade de acesso do habeas corpus, mas alcançam todos os direitos fundamentais.

imminente perigo de soffrer violencia por meio de prisão ou constrangimento illegal em sua liberdade de locomoção. "Sobre o tema, v., ainda, Sarmento, 2010, p. 26-27.

${ }^{41}$ A ação de tutela, principal mecanismo de proteção de direitos fundamentais na Colômbia, é regulada pelo art. 86 da Constituição e pelo Decreto $n^{\circ} 2.591 / 91$, e se destina a proteger direitos ameaçados ou violados pela ação ou omissão de qualquer autoridade pública ou de particulares. Pode ser ajuizada por qualquer pessoa, por si mesma ou por alguém que atue em seu nome (incluindo o defensor del Pueblo e procuradores), incluindo menores de idade, estrangeiros e pessoas jurídicas nacionais ou estrangeiras, sem necessidade de advogado, em todo momento e lugar. A ação segue um procedimento sumário, célere e com preferência, devendo ser decidida em até 10 dias após seu ajuizamento. Não é necessário esgotar as vias administrativas e mesmo que o interessado interponha recursos administrativos pode ajuizar a ação de tutela a qualquer momento. Possui caráter subsidiário (só será cabível caso não haja outro meio de defesa judicial), o que pode ser afastado na hipótese de prejuízo irremediável. A proteção consiste numa ordem de fazer ou não fazer, podendo o juiz adotar o que considerar necessário para a proteção do direito.

A decisão do juiz de primeira instância pode ser objeto de impugnação. Juiz de instância superior irá rever a decisão, e o resultado, independentemente de qual seja, será enviado à Corte Constitucional para eventual revisão. A Corte tem liberdade para escolher os casos que irá revisar e algum magistrado ou o Defensor del Pueblo pode solicitar a revisão de uma ação específica. Os casos selecionados devem ser decididos em até três meses. A decisão da Corte só tem efeitos no caso concreto.

Sobre a ação de tutela colombiana e a Corte Constitucional do país, v. Sweet (2012), Soler (1997) e Alonso Freire (2015).

${ }^{42} \mathrm{O}$ recurso de amparo e o habeas corpus, previstos na Constituição costaquirrense e na Ley Orgánica del Poder Judicial (Ley $\left.n^{\circ} 7.333 / 93\right)$, são instrumentos complementares de proteção aos direitos fundamentais, cabendo o primeiro quando o direito em questão não for protegido pelo segundo. Toda pessoa tem direito ao habeas corpus para garantir sua liberdade e integridade e ao recurso de amparo para manter ou reestabelecer o gozo de outros direitos consagrados na Constituição ou os direitos de caráter fundamental previstos em instrumentos internacionais de direitos humanos. O recurso de amparo é cabível contra toda disposição, acordo ou resolução e, em geral, contra toda ação, omissão ou simples atuação material não fundada em um ato administrativo eficaz, dos servidores e órgãos públicos, que tenham violado, violem ou ameacem violar qualquer dos direitos mencionados. Também contra ações ou omissões fundadas em normas interpretadas incorretamente ou aplicadas indevidamente é cabível o recurso.

As ações podem ser ajuizados por qualquer pessoa, nacional ou estrangeira, independentemente de idade, dia do ano e da semana e horário, além de não ser necessário o recolhimento de custas processuais. Na maioria dos casos, não é preciso advogado. As petições podem ser apresentadas em qualquer material e em qualquer idioma, inclusive em Braille, podendo ser escritas a próprio punho. O procedimento é marcado pela celeridade, não podendo os magistrados invocar a inércia das partes para retardá-lo. Os prazos legais não podem ser prorrogados nem retardados no seu cumprimento. A jurisprudência e os precedentes da Sala Constitucional são vinculantes e tem efeitos erga omnes, exceto para ela mesma, e aqueles que descumprirem as decisões estão sujeitos às sanções legais.

A proteção varia de acordo com o ato impugnado, podendo consistir, por exemplo, na ordenação de cessação de uma conduta ou no estabelecimento de prazo peremptório para a realização de um ato.

Sobre o recurso de amparo costarriquense e a Corte Constitucional do país, v. Fallas (1999), Wilson (2011, 2012) e Alonso Freire (2015). 
Revista da Faculdade de Direito-RFD-UERJ - Rio de Janeiro, n. 29, jun. 2016

O mandado de segurança, criado para suprir a lacuna deixada pela reforma à Constituição de 1891 que restringiu o escopo do habeas corpus ${ }^{43}$, consagra uma série de requisitos (como prazo de 120 dias, necessidade de apontar a autoridade, imposição de representação por advogado) que dificultam seu manejo, tornando-o uma modalidade processual particularmente apropriada para o direito da burocracia (tributos e direitos dos servidores públicos). Ao mesmo tempo, as ações simplificadas dos Juizados Especiais (Leis $\left.\mathrm{n}^{\mathrm{o}} 9.099 / 95, \mathrm{n}^{\mathrm{o}} 10.259 / 01 \mathrm{e}^{\mathrm{o}} 12.153 / 09\right)$, em que pese terem ampliado enormemente o acesso ao Judiciário, não possuem caráter mandamental, o que as torna particularmente eficientes para discussão de temas envolvendo direitos disponíveis e de caráter prestacional, mas pouco apropriadas para a tutela rápida de liberdades existenciais.

$\mathrm{Na}$ linha do que apontei, a despeito do amplo leque de ações contemplado na Constituição de 1988 ainda nos falta uma ferramenta processual específica apta a expandir a cultura de direitos fundamentais na base do Judiciário, pulverizando a gramática desses direitos. Não se pode perder de vista que as estruturas processuais têm uma conexão direta com a formação da mentalidade dos operadores do Direito, de modo que a criação de uma ação de tutela e a facilitação do acesso pode também gerar um fortalecimento do compromisso dos juristas com a promoção dos direitos fundamentais.

Um exemplo da acentuada resistência que existe em nosso sistema quanto à ampliação do acesso dos cidadãos ao Judiciário é o que ocorreu no processo de estruturação da ADPF ${ }^{44}$. O Projeto de Lei 2.872/97, posteriormente convertido na Lei da ADPF, previa no inciso II do art. $2^{\circ}$ que "qualquer pessoa lesada ou ameaçada por ato do Poder Público" poderia propor a Arguição, o que a converteria em um instrumento de cidadania e de defesa dos direitos fundamentais. A Mensagem $\mathrm{n}^{\circ} 1.807 / 99$, porém, vetou tal inciso (v. supra, nota $\mathrm{n}^{\circ} 21$ ), causando grande perplexidade e alterando a proposta original da ADPF (BARROSO, 2011, p.

\footnotetext{
${ }^{43}$ A doutrina brasileira do habeas corpus está intimamente conectada com a criação do mandado de segurança: para proteger as liberdades no judiciário, era preciso de uma garantia que fosse além da proteção da liberdade de locomoção, motivo pelo qual a discussão jurídica sobre o tema levou à criação do mandado de segurança, previsto no art. 113 da Constituição de 1934. Com exceção da Constituição de 1937, de caráter autoritário, todas as demais previram o writ of mandamus. Sobre o tema, v. Souza (2008).

${ }^{44}$ Os legitimados à propositura de ADPF, que são os mesmos para propor ADI e ADC, se dividem entre legitimados universais e especiais, de acordo com a necessidade de demonstração de pertinência temática. Não bastasse a restrição feita por tal requisito, o STF conferiu interpretação restritiva aos legitimados ativos, exigindo, por exemplo, que as entidades de classe de âmbito nacional sejam de natureza econômica ou profissional e tenham representação em, pelo menos, nove estados da federação (neste sentido, v. BRASIL, Supremo Tribunal Federal, ADI 4230 AgR, Tribunal Pleno, Relator Min. Dias Toffoli, julgado em 01 ago. 2011, DJe 14 set. 2011; BRASIL, Supremo Tribunal Federal, ADI 4912, Tribunal Pleno, Relator Min. Edson Fachin, julgado em 11 mai. 2016, DJe 24 mai. 2016).
} 
300). Segundo o veto, um acesso individual e irrestrito seria incompatível com o controle concentrado de constitucionalidade e haveria elevação excessiva do número de feitos a reclamar apreciação pelo STF, "sem a correlata exigência de relevância social e consistência jurídica das argüições propostas", já que o proponente da arguição não precisaria ostentar nenhum requisito específico e o objeto da ação é dotado de generalidade ${ }^{45}$.

Em vista desse contexto, entendo que duas mudanças legislativas seriam aptas a promover uma maior proteção dos direitos fundamentais de baixo (da base) para cima (cúpula). Primeiramente, a criação de uma ação de tutela nos moldes da ação de habeas corpus, ou, alternativamente, a remoção dos requisitos estabelecidos para o mandado de segurança. Em segundo lugar, a revisão da lei da ADPF, restaurando o comando legislativo vetado na proposta original.

No âmbito do próprio STF, há mudanças de paradigma que poderiam ser implementadas pela jurisprudência e pelo próprio agir individual dos ministros ${ }^{46}$. Considerando o congestionamento da corte, especialmente no que toca às repercussões gerais, que ensejam a suspensão do trâmite das ações em curso nas demais instâncias, a atribuição de prioridade às ações envolvendo direitos fundamentais seria um ato com forte efeito simbólico e pedagógico.

A promoção de direitos fundamentais pressupõe a inclusão dos titulares de direitos no processo de interpretação constitucional, e esse fenômeno só se realiza de forma efetiva se os critérios de acesso à Corte - e de utilização desses mecanismos - forem objetivos, transparentes e igualitários. Entretanto, como se sabe, o acesso aos tribunais é limitado por um acervo de entendimentos restritivos - chamados de "jurisprudência defensiva" 47 - que impactam de forma desproporcional grupos mais vulneráveis, os quais não têm acesso à advocacia especializada na atuação perante cortes superiores, um serviço custoso e, portanto, restrito a uma parcela diminuta dos jurisdicionados ${ }^{48}$.

\footnotetext{
45 Além destes aspectos, cabe mencionar, ainda, o princípio da subsidiariedade. Previsto no $\S 1^{\circ}$ do art. $4^{\circ}$ da Lei 9.882/97, este princípio indica que a ADPF só será cabível quando não houver qualquer outro meio capaz de sanar a lesividade. Uma aplicação rigorosa deste princípio pode reduzir a ADPF a um "apêndice do sistema de fiscalização concentrada de inconstitucionalidade e a chamada ADPF incidental será, na prática, uma inutilidade, museu de intenções" (SAMPAIO, 2013, p. 652).

${ }^{46}$ Neste sentido, v. Arguelhes; Ribeiro (2015).

${ }^{47}$ Sobre o conceito em questão, veja-se Alexandre Freire; Castro (2013).

${ }^{48}$ A teoria do impacto desproporcional foi desenvolvida na jurisprudência norte-americana sobre discriminação no campo trabalhista e tem aplicações em vários ramos do Direito. Sua aplicação no domínio processual pareceme um desdobramento lógico da ideia de igualdade. Sobre a origem da disparate impact theory veja-se Hunter; Shoben (1998). Ainda sobre o tema: Willborn (1985).
} 
Revista da Faculdade de Direito-RFD-UERJ - Rio de Janeiro, n. 29, jun. 2016

Os bloqueios e a dificuldade de acesso ao sistema poderiam ser amenizados caso o STF revisse sua interpretação quanto aos legitimados para deflagrar a jurisdição abstrata, rompendo com a criação jurisprudencial de exigência de demonstração de pertinência temática ${ }^{49}$ para a propositura da ação de constitucionalidade por entidades de classe de âmbito nacional $^{50}$. O Supremo Tribunal Federal, nesse ponto, fabricou um filtro processual não previsto na Constituição, que limita severamente o acesso da sociedade civil organizada à fiscalização abstrata de constitucionalidade, favorecendo a proteção dos direitos de grupos já sobreincluídos $^{51}$. Isso porque a Corte, em relação a tais legitimados, atrelou a possibilidade de acesso à demonstração de interesses econômicos ${ }^{52}$, valorizando, assim, a tutela de direitos patrimoniais de grupos sobreincluídos, ao mesmo tempo em que dificulta o acesso da sociedade civil para o fim de proteger direitos existenciais e direitos de grupos marginalizados e subincluídos ${ }^{53}$.

\footnotetext{
${ }^{49}$ Pertinência temática é um conceito puramente jurisprudencial, que nas palavras do Ministro Celso de Mello “(...) se traduz na relação de congruência que necessariamente deve existir entre os objetivos estatutários ou as finalidades institucionais da entidade autora e o conteúdo material da norma questionada em sede de controle abstrato". V. BRASIL. Supremo Tribunal Federal. Ação Direta de Inconstitucionalidade no $1157-\mathrm{MC}$, Tribunal Pleno, Rel. Min. Celso Mello, julgamento em 01 dez. 1994, DJ 11 nov. 2006.

${ }^{50}$ O Supremo Tribunal Federal, por aplicação analógica da Lei no 9.096/95 (Lei Orgânica dos Partidos Políticos), entende que a comprovação do âmbito nacional das entidades de classe se funda na "existência de associados ou membros em pelo menos nove Estados da Federação", v. BRASIL. Supremo Tribunal Federal. Ação Direta de Inconstitucionalidade $\mathrm{n}^{\mathrm{o}}$ 108-QO, Tribunal Pleno, Rel. Min. Celso Mello, julgamento em 29 ago. 1992. Esse critério objetivo, todavia, pode causar distorções representativas relevantes, como no caso de atividades profissionais eminentemente regionalizadas (tais como seringueiros e artesãos), ou de difícil organização associativa.

${ }^{51}$ Sobre o conceito de sobreinclusão e subinclusão, veja-se Marcelo Neves (1994): "No contexto social brasileiro, cabe falar de duas formas parciais de exclusão.

De um lado, a subinclusão significa que amplos setores sociais dependem das exigências dos subsistemas da sociedade mundial complexa (ter conta no banco, educação formal, saúde etc), mas não têm acesso aos respectivos benefícios. No campo do direito, isso implica subordinação aos deveres impostos pela ordem jurídica, mas falta de acesso a direitos básicos.

De outro lado, a sobreinclusão significa que certos setores privilegiados têm acesso aos benefícios dos sistemas sociais, mas não se subordinam às suas imposições restritivas, o que implica exercício dos direitos sem subordinação aos deveres.

É claro que não há o absolutamente subincluído ou sobreincluído, mas há uma forte tendência à generalização de relações de subinclusão e sobreinclusão no direito intimamente vinculadas à atuação arbitrariamente seletiva dos agentes estatais, sobretudo da polícia e do Judiciário."

52 Vale ressaltar que, no entendimento da Corte, sequer estão legitimados à propositura de ação de controle normativo em abstrato as entidades de classe que reúnam membros de diversas categorias profissionais. Trata-se da ilegitimidade conferida à Confederação dos Servidores Públicos do Brasil, cuja "heterogeneidade da composição (...) descaracteriza a condição de representatividade de classe". V. BRASIL. Supremo Tribunal Federal. Ação Direta de Inconstitucionalidade $\mathrm{n}^{\circ}$ ADI no 3.850-AgR, Tribunal Pleno, Rel. Min. Eros Grau, julgamento em 22 abr. 2009, DJe 14 ago. 2009.

${ }_{53}$ A respeito da influência dos ministros do STF na Assembleia Constituinte, descrevendo a defesa destes no sentido de que não se ultimasse a ampliação do catálogo de legitimados para deflagrar o controle de constitucionalidade, confira-se o excelente artigo de Diego Werneck Arguelhes (2014).
} 
Além disso, a realização de audiências públicas e a aceitação de amicus curiae não estão atualmente submetidas a qualquer critério objetivo e controlável, constituindo uma decisão discricionária do relator. Muitos estudos realizados nos últimos anos demonstram a seletividade e a ausência de transparência e objetividade no uso desses instrumentos pelo STF, o que compromete a leitura de que possam ser entendidos como autênticas ferramentas de democratização ${ }^{54}$. Nesse contexto, seria relevante que o STF fixasse regras claras, objetivas e impessoais que determinassem os casos em que as audiências seriam realizadas e quem poderia ser ouvido.

Assim, em que pese a complexidade e amplitude do sistema de controle de constitucionalidade brasileiro, ele é ainda substancialmente seletivo e elitizado, impondo-se um conjunto de medidas legislativas e jurisprudenciais comprometidas com a inclusão e a facilitação do acesso ao Judiciário por grupos subrepresentados.

\section{ENCERRAMENTO}

A possibilidade de se promoverem revoluções de direitos por meio do Poder Judiciário não é pacífica. Há quem, como afirma Gerald Rosenberg (1991) em relação ao sistema norteamericano, entenda que essa é uma esperança vazia, pois a Suprema Corte daquele país não teve um papel tão decisivo na mudança dos direitos quanto se supõe. Ainda em relação aos Estados Unidos, Charles Epp (2009) sustenta que essa revolução por meio das Cortes pode ser feita, mas depende da construção de um suporte de apoio jurídico aos atores sociais para que se efetive. Não existe uma resposta unívoca à essa questão. É que a pretensão de que o processo judicial sirva como elemento de inclusão e democratização do direito constitucional encerra um paradoxo, que deflui da necessidade de a sociedade civil organizada exigir a implementação de mecanismos legais e a adoção de entendimentos jurisprudenciais que tornem o Judiciário menos hermético e mais acessível. A possibilidade de o direito funcionar como ferramenta de transformação dependerá, portanto, de elementos externos a ele. Para que o processo judicial possa servir como instrumento de emancipação é indispensável que o Poder Legislativo seja convencido a promover uma reformulação dos mecanismos processuais de tutela dos direitos fundamentais, e que os próprios tribunais sejam persuadidos

\footnotetext{
${ }^{54}$ Nesse sentido, vejam-se Guimarães (2009), Medina (2010) e Camargo (2011).
} 
Revista da Faculdade de Direito-RFD-UERJ - Rio de Janeiro, n. 29, jun. 2016

a rever entendimentos que constituem obstáculos à vocalização de demandas pelos grupos marginalizados.

\section{REFERÊNCIAS}

ALEXANDER, S. L. Covering the courts: a handbook for journalists. 2. ed. Oxford: Rowman \& Littlefield, 2003.

ANDERSON, Gavin W. Human Rights and the Global South. In: CAMPBELL, Tom; EWING, K. D.; TOMKINS, Adam. The Legal Protection of Human Rights: Sceptical Essays. New York: Oxford University Press, 2011, p. 347-365.

ARGUELHES, Diego Werneck. Poder não é querer: preferências restritivas e redesenho institucional no Supremo Tribunal Federal pós-democratização. Universitas JUS, Brasília, v. 25, n. 1, p. 25-45, 2014.

; RIBEIRO, Leandro Molhano. O Supremo Individual: mecanismos de influência direta dos Ministros sobre o processo político. Direito, Estado e Sociedade, Rio de Janeiro, v. 46, p. 121-155, jan./jun. 2015.

; __. Quando a unanimidade não esclarece. Valor Econômico, Rio de Janeiro, jun. 2012. Disponível em: <http://www.valor.com.br/legislacao/2724050/quandounanimidade-nao-esclarece>. Acesso em: 04 jun. 2016.

BARROSO, Luís Roberto. A Razão Sem Voto: o Supremo Tribunal Federal e o Governo da Maioria. In: SARMENTO, Daniel (coord.). Jurisdição Constitucional e Política. Rio de Janeiro: Forense, 2015, p. 3-34.

Constituição, Democracia e Supremacia Judicial: Direito e Política no brasil Contemporâneo. In: Fórum, 2013a, p. 237-283. . O Novo Direito Constitucional Brasileiro. Belo Horizonte:

O Controle de Constitucionalidade no Direito Brasileiro: exposição sistemática da doutrina e análise crítica da jurisprudência. 5. ed. rev. e atual. São Paulo: Saraiva, 2011.

Uniões homoafetivas: reconhecimento jurídico das uniões estáveis entre parceiros do mesmo sexo. In: O Novo Direito Constitucional Brasileiro: contribuições para a construção teórica e prática da jurisdição constitucional no Brasil. Belo Horizonte: Fórum, 2013b, p. 421-445.

BAUM, Lawrence; DEVINS, Neal. Why the Supreme Court Cares About Elites, Not the American People. The Georgetown Law Journal, Washington (DC), v. 98, p. 1515-1581, 2010.

Judges and their audiences. Princeton: Princeton University Press, 2006. 
BRASIL. Congresso Nacional. Câmara dos Deputados. Comissão Parlamentar de Inquérito do Sistema Carcerário. Brasília: Câmara dos Deputados, 2009. Disponível em: $<$ http://bd.camara.gov.br/bd/bitstream/handle/bdcamara/2701/cpi_sistema_carcerario.pdf?seq uence=1>. Acesso em: 09 jun. 2016.

BRESCIA, Raymond H.; OHANIAN, Edward J. The Politics of Procedure: An Empirical Analysis of Motion Practice in Civil Rights Litigation Under the New Plausibility Standard, Akron Law Review, Akron, v. 46, p. 329-373, 2013.

CAMARGO, Margaria Maria Lacombe. As audiências públicas no Supremo Tribunal Federal: o exemplo da ADPF 54, 2011. Disponível em: <http://www.publicadireito.com.br/artigos/?cod=01d8bae291b1e472>. Acesso em: 30 nov. 2014.

CAMPOS, Carlos Alexandre de Azevedo. Da inconstitucionalidade por omissão ao 'Estado de coisas inconstitucional'. 2015. Dissertação (Mestrado em Direito Público) Universidade do Estado do Rio de Janeiro, Rio de Janeiro, 2015.

Explicando o avanço do ativismo judicial do Supremo Tribunal Federal. Revista do Instituto do Direito Brasileiro, v. 2, n. 8, p. 7881-7961, 2013.

CARRINGTON, Paul D. Politics and Civil Procedure Rulemaking: Reflections on Experience. Duke Law Journal, Durham, v. 60, p. 597-667, 2010.

CLÈVE, Clèmerson Merlin. A Fiscalização Abstrata da Constitucionalidade no Direito Brasileiro. 2. ed. rev., atual. e ampl. São Paulo: Revista dos Tribunais, 2000.

COHN, Marjorie; DOW, David. Cameras in the courtroom: Television and the Pursuit of Justice. Lanham: Rowman \& Littlefield, 1998.

COSTA, Alexandre Araújo; BENVINDO, Juliano Zaiden. A Quem Interessa o Controle Concentrado de Constitucionalidade? O Descompasso entre Teoria e Prática na Defesa dos Direitos Fundamentais. (Working Paper) Universidade de Brasília, Brasília, 2014. Disponível em: <http://ssrn.com/abstract=2509541>. Acesso em: 27 mai. 2016.

DAHL, Robert. Decision-making in a democracy: the Supreme Court as a national policy maker. Journal of Public Law, v. 6, p. 279-295, 1957.

DANTAS, Bruno. Repercussão Geral: perspectivas histórica, dogmática e de direito comparado - questões processuais. 3. ed. rev., atual. e ampl. Rio de Janeiro: Revista dos Tribunais, 2012.

DINIZ, Debora. Vírus Zika e mulheres, Caderno de Saúde Pública, Rio de Janeiro, v. 32, n. 5, p. 1-4, mai. 2016.

DWORKIN, Ronald. What is Equality? Part 4: Political Equality, University of San Francisco Law Review, v. 22, n. 1, p. 1-30, 1987.

EISGRUBER, Christopher. Constitucional Self-government. Cambridge: Harvard University Press, 2001. 
EPP, Charles R. Making Rights Real: Activists, Bureaucrats, and the Creation of the Legalistic State. Chicago: The University of Chicago Press, 2009.

FALCÃO, Joaquim; CERDEIRA, Pablo de Camargo; ARGUELHES, Diego Werneck. I Relatório Supremo em Números: O Múltiplo Supremo. Rio de Janeiro: FGV Rio. 2011.

FALlAS, Alex Solís. La Dimensíon Política de la Justicia Constitucional. San José: Asamblea Legislativa de Costa Rica, 1999.

FONTE, Felipe de Melo. A Sociedade Aberta de Telespectadores: Televisionamento, Opinião Pública e Legitimidade da Jurisdição Constitucional. 2016. Tese. (Doutorado em Direito Público). Universidade do Estado do Rio de Janeiro, Rio de Janeiro, 2016.

FRANKENBERG, Günther. A Gramática da Constituição e do Direito. Belo Horizonte: Del Rey, 2007.

FREIRE, Alexandre Reis Siqueira; CASTRO, Marcello Soares. O juízo de admissibilidade do recurso extraordinário no projeto do novo Código de Processo Civil brasileiro. Revista Jurídica UNIGRAN, v. 15, n. 29, jun. 2013. Disponível em: $<$ http://www.unigran.br/revista_juridica/ed_anteriores/29/artigos/artigo01.pdf $>$. Acesso em 10 jun. 2016.

FREIRE, Alonso. Desbloqueando os canais de acesso à jurisdição constitucional do STF: por que não também aqui uma revolução de direitos? In: SARMENTO, Daniel (coord.). Jurisdição Constitucional e Política. Rio de Janeiro: Forense, 2015, p. 591-640.

FRIEDMAN, Barry. The will of the people: how public opinion has influenced the Supreme Court and shaped the meaning of the constitution. New York: Macmillan, 2009.

GAZZOLA, Luciana De Paula Lima; MELO, Frederico Henrique Corrêa. Anencefalia e anomalias congênitas: contribuições do patologista ao Poder Judiciário. Revista Bioética, Brasília, n. 3, v. 23, p. 495-504, 2015.

GOMES, Juliana Cesario Alvim. Por um constitucionalismo difuso: cidadãos, movimentos sociais e o significado da Constituição. 2014. Dissertação (Mestrado em Direito Público) Universidade do Estado do Rio de Janeiro, Rio de Janeiro, 2014.

GUIMARÃES, Aline Lisbôa. Participação social no controle de constitucionalidade: o desvelamento da restrição nas decisões do Supremo Tribunal Federal. Dissertação (Mestrado em Direito) - Universidade de Brasília, Brasília, 2009. Disponível em: < http://repositorio.unb.br/bitstream/10482/3895/1/2009_AlineLisboaNavesGuimaraes.pdf> Acesso em: 30 nov. 2014.

HUNTER, Rosemary C.; SHOBEN, Elaine W.. Disparate impact discrimination: American oddity or internationally accepted concept? Berkley Journal of Employment and Labor Law, v. 19, n. 1, 1998.

JANSEN, Rodrigo. A Súmula Vinculante como Norma Jurídica. Revista dos Tribunais, Rio de Janeiro, v. 838, p. 42-74, ago. 2005. 
KAUFMAN, N.; LINDQUIST, S. Critiquing gender-neutral treaty language: the Convention on the Elimination of All Discrimination against Women. In: PETERS, J.; WOLPER, A. (eds). Women's Rights, Human Rights: International Feminist Perspectives. New York: Routledge, 1995, p. 114-125.

KRAMER, Larry. The Supreme Court 2000 Term Forward: We the Court. Harvard Law Review, v. 5, p. 4-169, 2001.

LAIN, Corinna Barret. Upside-down Judicial Review. The Georgetown Law Journal, v. 101, 113-183, 2012.

MARTINS, Ana Paula Antunes; CERQUEIRA, Daniel; MATOS, Mariana Vieira Martins. A institucionalização das políticas públicas de enfrentamento à violência contra as mulheres no Brasil (Nota Técnica). Instituto de Pesquisa Econômica Aplicada, Brasília, mar. $2015 . \quad$ Disponível em: <http://www.ipea.gov.br/portal/images/stories/PDFs/nota_tecnica/150302_nt_diest_13.pdf >. Acesso em: 11 jun. 2016.

MAUS, Ingeborg. Judiciário Como Superego da Sociedade: O Papel da Atividade Jurisprudencial na "Sociedade Órfã". Novos Estudos CEBRAP, São Paulo, n. 58, p. 183202, nov. 2000.

MCELROY, Lisa T. Cameras at the Supreme Court: a Rhetorical analysis. Brigham Young University Law Review, n. 6, p. 1837-1900, 2012.

MEDINA, Damares. Amicus Curiae: amigo da corte ou amigo da parte? São Paulo: Saraiva, 2010.

MELlO, Patrícia Perrone Campos. Nos bastidores do Supremo Tribunal Federal: Constituição, emoção, estratégia e espetáculo. São Paulo: GEN, 2015.

MINISTÉRIO DA SAÚDE. Secretaria de Vigilância em Saúde. Programa Nacional de DST e Aids. O Remédio via Justiça: Um estudo sobre o acesso a novos medicamentos e exames em HIV/aids no Brasil por meio de ações judiciais/Ministério da Saúde, Secretaria de Vigilância em Saúde, Programa Nacional de DST e Aids. Brasília: Ministério da Saúde, 2005.

MINOW, Martha. Politics and Procedure. In: KAIRYS, David (ed.). The Politics of Law: A Progressive Critique. 3. ed. New York: Basic Books, p. 101-132, 1998.

MOURA, Walter; LAZZARINI, Marilena. Planos Econômicos: Nova Veneza e o Supremo. Jota, Brasília, jun. 2016. Disponível em: <http://jota.uol.com.br/planos-economicos-novaveneza-e-o-supremo>. Acesso em: 04 jun. 2016.

NEVES, Marcelo. (1994), Entre subintegração e sobreintegração: a cidadania inexistente, Dados - Revista de Ciências Sociais, Rio de Janeiro, v. 37, n. 2, p. 253-276, 1994. 
NIGRO, Rachel. A decisão do STF sobre a união homoafetiva: uma versão pragmática da linguagem constitucional. Direito, Estado e Sociedade, Rio de Janeiro, n. 41, p. 157-183, jul./dez. 2012.

NONATO, Domingos do Nascimento; LEAL, Pastora do Socorro Teixeira. O direito à diferença, mas na igualdade de direitos: o reconhecimento pelo Supremo Tribunal Federal brasileiro da união homoafetiva enquanto entidade familiar. Revista de Direitos Fundamentais e Democracia, Curitiba, v. 10, n. 10, p. 224-259, jul./dez. 2011.

NOVELINO, Marcelo. A influência da opinião pública no comportamento judicial dos membros do STF. In: ___ FELLET, André. (Org.). Constitucionalismo e democracia. Salvador: Juspodivm, 2013, p. 265-328.

OLIVEIRA, Fabiana Luci. Agenda suprema: Interesses em disputa no controle de constitucionalidade das leis no Brasil. Revista de Sociologia da USP, São Paulo, v. 28, n. 1, p. 105-133, abr. 2016.

ORGANIZAÇÃO DAS NAÇÕES UNIDAS. Convenção Sobre a Eliminação de Todas as Formas de Discriminação contra as Mulheres. Recomendação Geral no 33. Disponível em: <http://monitoramentocedaw.com.br/wp-content/uploads/2013/08/Nova-RecomendaçãoGeral-da-Cedaw-2016-Nº-33-Acesso-à-Justiça-CEDAW-C-GC-33-P.pdf>. Acesso em: 11 jun. 2016.

PEREIRA, Jane Reis Gonçalves; GONÇALVES, Gabriel Accioly. Inconstitucionalidade sistêmica e multidimensional: transformações no diagnóstico das violações à Constituição. Revista Juris Poiesis, Rio de Janeiro, v. 18, n. 18, p. 130-159, jan./dez. 2015.

O Judiciário e a opinião pública: riscos e dificuldades de decidir sob aplausos e vaias.

Os Constitucionalistas, dez. 2012. Disponível em: <http://www.osconstitucionalistas.com.br/o-judiciario-e-a-opiniao-publica-riscos-edificuldades-de-decidir-sob-aplausos-e-vaias>. Acesso em: 06 jun. 2016.

Princípios Morais e Direitos Humanos na Obra de Carlos Santiago Nino. In: TORRES, Ricardo Lobo. (Org.). Legitimação dos direitos humanos. Rio de Janeiro: Renovar, 2002, p. 315-349.

Representação democrática do Judiciário: reflexões preliminares sobre os riscos e dilemas de uma ideia em ascensão. Revista Juris Poiesis, Rio de Janeiro, v. 17, 2014, p. 343 359.

Retrospectiva Direito Constitucional 2008: A expansão do judiciário e o constitucionalismo cosmopolita. Revista de Direito do Estado, v. 13, p. 23-53, 2009. PERUGINI, Nicola; GORDON, Neve. The Human Right to Dominate. New York: Oxford University Press, 2015.

PETTER, Andrew. Canada's Charter Flight: Soaring backwards into the Future. Journal of Law and Society, v. 16, n. 2, p. 151-165, 1989. 
Revista da Faculdade de Direito-RFD-UERJ - Rio de Janeiro, n. 29, jun. 2016

POST, Robert C.; SIEGEL, Reva B. Roe rage: democratic constitucionalism and blacklash. Harvard Civil Rights-Civil Liberties Law Review, 2007. Disponível em: <http://ssrn.com/abstract=990968>. Acesso em 30 nov. 2014.

RODRIGUES FILHO, José Marcos Vieira. Repercussão geral e o Supremo Tribunal Federal: Deficiências da modelagem atual e propostas para o aprimoramento do instituto. 2015. Dissertação (Mestrado em Direito Público) - Universidade do Estado do Rio de Janeiro, Rio de Janeiro, 2015.

ROSENBERG, Gerald N. The Hollow Hope: Can Courts Bring About Social Change? Chicago: The University of Chicago Press, 1991.

SAMPAIO, José Adércio. Arguição de Descumprimento de Preceito Fundamental: Entre o Ativismo e a Inanição Judicial. In: FELLET, André Luiz Fernandes; PAULA, Daniel Giotti de; NOVELINO, Marcelo. As Novas Faces do Ativismo Judicial. Salvador: Juspodivm, 2013, p. 643-682.

SARDENBERG, Cecilia Maria Bacellar; GROSSI, Miriam Pillar. Balanço sobre a lei Maria da Penha (Dossiê). Estudos Feministas, Florianópolis, v. 23, n. 2, mai./ago. 2015.

SARMENTO, Daniel. Por um constitucionalismo inclusivo: história constitucional brasileira, teoria da constituição e direitos fundamentais. Rio de Janeiro: Lumen Juris, 2010.

SILVA, Fernanda Duarte Lopes Lucas da. Uma Questão de Direito: a Homossexualidade e o Universo Jurídico. 2003. Tese (Doutorado em Direito Público) - Pontifícia Universidade Católica do Rio de Janeiro, Rio de Janeiro, 2003.

SILVA, Virgílio Afonso da. Definição das medidas provisórias vigentes em cada fase do plano Collor e de seus efeitos especialmente no que se refere à correção de depósitos bancários. Revista de Direito Bancário e do Mercado de Capitais, v. 56, p. 375-397, abr. 2012.

SOLER, Manuel Barreto; ANZOLA, Libardo Sarmiento. Constitución Política de Colombia Comentada por la Comisión Colombiana de Juristas: Título II - De los Derechos, las Garantías y los Deberes. Bogotá: Comisión Colombiana de Juristas, 1997.

SOUZA, Luiz Henrique Boselli de. A doutrina brasileira do habeas corpus e a origem do mandado de segurança: análise doutrinaria de anais do Senado e da jurisprudência história do Supremo Tribunal Federal. Revista de Informação Legislativa, Brasília, n 177, p. 75-82, jan./mar. 2008.

STEPNIAK, Daniel. Audio-visual coverage of courts: a comparative analysis. Cambridge: Cambridge University Press, 2008.

SUNSTEIN, Cass R. Constitutional Personae. New York: Oxford University Press, 2015. SWEET, Alec Stone. Constitutional Courts. In: ROSENFELD, michel; SAJÓ, András (Eds.). The Oxford Handbook of Comparative Constitutional Law Oxford: Oxford University Press, 2012, p. 816-828. 
TEPEDINO, Gustavo. A Disciplina Civil-constitucional das Relações Familiares. In:

Temas de Direito Civil. 3. ed. rev. e atual. Rio de Janeiro: Renovar, 2004, p. 395-416.

TUMA, Clara. Open courts: how cameras in courts help keep the system honest. Clev., St. L. Rev., n. 49, 2001.

TUSHNET, Mark. Taking the constitution away from de the courts. Princeton: Princeton University Press, 1999.

VIEIRA, Oscar Vilhena. Supremocracia. Revista Direito GV, São Paulo, v. 4, n. 2, p. 441464, jul./dez. 2008.

WALDRON, Jeremy. On The Supreme Court Battlefield. The New York Review of Books, 24 mar. 2016. Disponível em: <http://www.nybooks.com/articles/2016/03/24/on-thesupreme-court-battlefield/>. Acesso em: 25 mai. 2016.

. The core of the case against judicial review. The Yale Law Journal, New Haven, p. 1346-1360, 2006.

WILLBORN, Steven L. The disparate model of discrimination: theory and limits. American University Law Review, v. 34, 1985.

WILSON, Bruce M. Constitutional Rights in the Age of Assertive Superior Courts: An Evaluation of Costa Rica's Constitutional Chamber of the Supreme Court. Willamette Law Review, v. 48, p. 451-471, 2012.

Enforcing Rights and Exercising an Accountability Function: Costa Rica's Constitutional Chamber of the Supreme Court. In: HELMKE, Gretchen; RÍOS-FIGUEROA, Julio. Courts in Latin America. New York: Cambridge University Press, 2011, p. 55-80.

ZURN, Christopher F. Deliberative Democracy and the Institutions of Judicial Review. New York: Cambridge University Press, 2007. 